\title{
A Review of Hepatoprotective Plants Used in Saudi Traditional Medicine
}

\author{
Abdulrahman K. Al-Asmari, ${ }^{1}$ Abdulrahman M. Al-Elaiwi, ${ }^{2}$ Md Tanwir Athar, ${ }^{1}$ \\ Mohammad Tariq, ${ }^{1}$ Ahmed Al Eid, ${ }^{3}$ and Saeed M. Al-Asmary ${ }^{4}$ \\ ${ }^{1}$ Department of Research, Prince Sultan Military Medical City, P.O. Box 7897 (775s), Riyadh, Saudi Arabia \\ ${ }^{2}$ Department of Urology, Prince Sultan Military Medical City, P.O. Box 7897 (775s), Riyadh, Saudi Arabia \\ ${ }^{3}$ Department of Clinical Pharmacy, Prince Sultan Military Medical City, P.O. Box 7897 (775s), Riyadh, Saudi Arabia \\ ${ }^{4}$ Department of FCM, Prince Sultan Military Medical City, P.O. Box 7897 (775s), Riyadh, Saudi Arabia
}

Correspondence should be addressed to Abdulrahman K. Al-Asmari; abdulrahman.alasmari@gmail.com

Received 3 June 2014; Revised 17 September 2014; Accepted 18 September 2014; Published 18 December 2014

Academic Editor: Mohammed Rahmatullah

Copyright (c) 2014 Abdulrahman K. Al-Asmari et al. This is an open access article distributed under the Creative Commons Attribution License, which permits unrestricted use, distribution, and reproduction in any medium, provided the original work is properly cited.

\begin{abstract}
Liver disease is one of the major causes of morbidity and mortality across the world. According to WHO estimates, about 500 million people are living with chronic hepatitis infections resulting in the death of over one million people annually. Medicinal plants serve as a vital source of potentially useful new compounds for the development of effective therapy to combat liver problems. Moreover herbal products have the advantage of better affordability and acceptability, better compatibility with the human body, and minimal side effects and is easier to store. In this review attempt has been made to summarize the scientific data published on hepatoprotective plants used in Saudi Arabian traditional medicine. The information includes medicinal uses of the plants, distribution in Saudi Arabia, ethnopharmacological profile, possible mechanism of action, chemical constituents, and toxicity data. Comprehensive scientific studies on safety and efficacy of these plants can revitalise the treatment of liver diseases.
\end{abstract}

\section{Introduction}

Since the dawn of history plants have played an important role in the treatment of human ailments. By trial and error the ancient population was relieving their sufferings by using herbs in a very primitive way. The history of many drugs which are in practice today could be traced back to the Hellenic civilization; drugs like castor oil, opium, olive, anise, peppermint, saffron, henbane, acacia, and yeast are mentioned in Egyptian Ebers Papyrus (1500 B.C.). Babylonians and Assyrians have mentioned a large number of herbal medicines, for example, coriander, cinnamon, liquorice, and so forth. Thya, written by the Chinese physician Chou Kung, in about 1100 B.C., describes the use of a number of plant drugs. The books of Sustruta, written in India at the beginning of the Christian era, describe some seven hundred herbal medicines. According to the recent analysis, man is recycled plant and plants fulfill a variety of human needs, as they are the source of nourishment, health, and pleasure [1]. Even the lowest form of plant life can be vital, and penicillin is only one - no doubt-the most famous antibiotics.

1.1. Greeko-Arab System of Medicine. Greeko-Arab system of medicine is a well-documented system of traditional medicine which was originated by Greek physicians and philosophers and enriched by Arabs. It was the work of the Greek philosopher-physician Hippocrates (460-377 B.C.), who freed herbal supplements from the realm of superstition and magic and gave it the status of science. He considered illness to be natural rather than a supernatural phenomenon, and he strongly suggested that herbal supplements should be administered without ritual ceremonies or magic [1]. After Hippocrates, Galen (131-200 A.D.) stands out for his contribution to traditional medicine. Galen introduced and practiced herbal medicine in preIslamic Egypt, serving as royal court physician to the king of Egypt [2]. Under his patronage, hundreds of new herbal supplements were researched, experimented, and developed for the treatment of almost all 
types of diseases. Galen's contributions in herbal remedies is highly regarded, even today the term galenical is applied to simple vegetable extractives. Arabs like Rhazes (850-932 A.D.), Avicenna (980-1037 A.D.), Al-Bitar (1180-1248 A.D.), and Al-Antaki (1510-1587) constructed an imposing edifice of Arab traditional medicine. "Avicenna" (the western name for Abu Sina), an Arab philosopher and physicist who wrote "Kitab-al-shifa" (The Canon of Medicine), is highly noteworthy. According to Greeko-Arab system of medicine, disease is a natural process resulting from the imbalance of various humors in the body. The humoral theory presupposes the presence of four humors: dam (blood), balgham (phlegm), safra (yellow bile), and sauda (black bile) in the body. The temperaments of persons are expressed by the words sanguine, phlegmatic, choleric, and melancholic according to the preponderance of the following four humors in their body, namely, blood, phlegm, yellow bile, and black bile, respectively. The humors themselves are assigned temperaments. Blood is hot and moist, phlegm is cold and moist, and yellow bile is hot and dry. According to the Greeko-Arab system herbs may restore humor imbalance and cure the diseases [3].

Greeko-Arab physicians identified the liver as one of the three principal organs of the body, along with the heart and the brain. According to Galen the liver is the "master organ" of the human body, arguing that it emerges before all other organs in the fetus formation. In his book entitled "On the Usefulness of the Parts of the Body" Galen described the liver as warm and moist organ involved in blood formation and principle instrument of sanguification. According to Avicenna liver is "the seat of nutritive or vegetative faculties" and "the seat of manufacture of the dense part of the humors". According to Arab physicians, malfunction of liver may lead to a variety of diseases which may be corrected by appropriate herbal intervention.

1.2. Liver Diseases and Their Global Burden. Liver is the largest and most vital organ of the human body. Besides its crucial role in the metabolism of nutrients, liver is responsible for biotransformation of drugs and chemicals thereby protecting body against toxic foreign materials. In this process the liver is exposed to high concentration of toxic chemicals and their metabolites which may cause liver injury. There are more than hundred well known liver diseases with diversified etiopathology. The most frequent causes of hepatic disease include infectious agents (especially hepatitis viral A, B, and C), obesity related fatty liver disease, xenobiotics (alcohol, drugs, and chemicals) induced liver injury, inherited and genetic defects related liver diseases, autoimmune hepatitis, liver cirrhosis, and primary or secondary liver cancer.

Liver diseases are one of the leading causes of morbidity and mortality across the world. Around 1.3 million deaths worldwide are due to chronic viral hepatitis. Many clinic-led researchers have found that liver related mortality is as high as fourth for some age group and eighth overall. According to WHO estimates, about 1.4 million cases of hepatitis A occur annually and 2 billion people worldwide are infected with the hepatitis B virus. About 350 million live with chronic infection and 600,000 persons die each year due to the acute or chronic consequences of hepatitis B. About 130-170 million people are chronically infected with hepatitis $C$ virus, and more than 350,000 people die from hepatitis C-related liver diseases each year [4]. The recent statistics clearly show that global burden of liver disease has increased over time with a huge impact on overall world population.

1.3. A Tilt towards Herbal Drugs. The treatment options for common liver diseases are limited due to the lack of hepatoprotective drugs in allopathic medicine. Moreover therapies developed along the principle of western medicine are often limited in efficacy, carry the risk of adverse effects, and are often too costly, especially for the habitants of developing world. For example, the effectiveness of treatments such as those using corticosteroids and interferon is inconsistent, carried the risk of adverse events, and is often too costly [5]. On the other hand plant derived compounds are easily accessible and affordable. There is a deep belief that herbal remedies symbolize safety because they are "natural" and fit into the image of a gentle and, therefore, harmless alternative to synthetic drugs. No doubt that herbs are staging a comeback and herbal "renaissance" is happening all over the world. Several recent surveys from Europe and the United States have demonstrated a sharp rise in the popularity and use of botanical drugs within a few years, with up to $65 \%$ of liver patients taking herbal preparations. The fact is that reliable hepatoprotective drugs are explicitly inadequate, and the search for natural herbal drugs has intensified in the recent decades.

In this review we summarized the scientific data published on thirty-five hepatoprotective plants used in Saudi Arabian traditional medicine, description of the plants and their distribution in Saudi Arabia, medicinal uses, experimental pharmacological studies, possible mechanism of action, chemical constituents, and toxicity studies.

\section{Methodology}

A list of hepatoprotective plants used in Saudi Arabia was prepared based on a nationwide survey of herbal drug used in traditional medicine for liver ailment by

(a) interviewing the patients visiting primary care centres of military hospitals of different regions of Saudi Arabia,

(b) review of traditional medicinal books/publications and folklore information.

A thorough of survey of literature on the pharmacological profile of these plants was undertaken to collect the published data for the period between 1975 and 2014 AD by using "Pubmed" and "Google Scholar" search engines. Attempt was made to determine if these plants have been tested for hepatoprotective activity using well-established experimental models including carbon tetrachloride $\left(\mathrm{CCl}_{4}\right)$, thioacetamide, paracetamol, ethanol, and morphine induced liver damage. The liver enzymes including aspartate transaminase (AST), alanine transaminase (ALT), alkaline phosphatase (APT), total protein (TP), and albumin (Alb) were used as a marker of liver injury. Literature search also included reversal of toxin induced histopathological changes by plant drugs. 
An attempt has been made to illustrate possible mechanism of hepatoprotective herbs with special reference to their antioxidant (ability to normalize oxidative stress markers) and inflammatory mediators. Available data about the chemical constituent of the hepatoprotective plants and their toxicity has also been presented.

Briefly, this review summarises the information about 35 hepatoprotective herbal drugs used in Saudi traditional medicine (Table 1) for the treatment of liver diseases including their botanical name, family, and part of the plant used, distribution of plants in Saudi Arabia, and their use in traditional medicine. The results of hepatoprotective studies on each plant, possible mechanism of action, and their chemical composition and toxicity data have been presented.

\section{Results}

3.1. Apium graveolens Linn. Apium graveolens Linn. (family: Apiaceae) locally known as "Karfas" is a biennial or perennial glabrous herb with a heavy aromatic smell found in Najd region of Saudi Arabia [6]. Seeds of A. graveolens have been widely used in traditional medicine for the treatment of liver and spleen disorders, jaundice [7], rheumatism, gout, and other inflammatory diseases $[8,9]$.

The hepatoprotective activity of the methanolic extract of $A$. graveolens seed has been studied against $\mathrm{CCl}_{4}[10,11]$ and paracetamol [11, 12] induced liver damage. A. graveolens extract dose dependently attenuated the toxin induced biochemical (serum AST, ALT, APT, TP, and albumin) and histopathological changes in liver tissues. The protective activity of $A$. graveolens was comparable with silymarin a well-established hepatoprotective herbal drug [10, 12]. Acute toxicity studies on A. graveolens extract in rats showed no adverse symptoms. Lethal dose in $50 \%$ of rats $\left(\mathrm{LD}_{50}\right)$ was found to be of $7.5 \mathrm{~g} / \mathrm{kg}$ body weight (b.w.) clearly suggesting its large margin of safety [12]. Chronic toxicity studies on the extract also revealed no delirious effect or mortality over a period of 14 days [13].

The hepatoprotective effect of $A$. graveolens Linn. may be attributed to its anti-inflammatory [14] and antioxidant activities [15]. Phytochemical screening showed the presence of flavonoids, tannins, volatile oils, alkaloids, sterols, and triterpenes. Detailed chemical studies also showed the presence of limonene, $\mathrm{p}$-dimethyl styrene, $\mathrm{N}$-pertyl benzene, caryophyllene, $\alpha$-selinene, $\mathrm{N}$-butyl phthalide, and sedanenolide [13].

3.2. Artemisia scoparia Waldst.et Kit. Artemisia scoparia Waldst.et Kit. (family: Compositae) locally known as "Baeiteran/A'weejan" is an annual herb mostly found in eastern and Najd region of Saudi Arabia [6]. The aerial part of A. scoparia has long been used in folk medicine for the treatment of jaundice and other liver disorders $[16,17]$.

The hepatoprotective activity of hydroalcoholic extract of aerial parts $A$. scoparia was investigated against $\mathrm{CCl}_{4}$ $[18,19]$ and paracetamol [20] induced liver damage. The extract dose dependently attenuated hepatotoxin induced biochemical parameters (rise in serum AST and ALT) and prolongation of phenobarbital induced sleeping time clearly indicating its hepatoprotective action. Hepatotoxins like $\mathrm{CCl}_{4}$ and paracetamol significantly reduced the activity of drug metabolizing enzymes in liver, leading to the slowing of drug metabolism resulting in increased level of drugs such as barbiturates which results in prolongation of their pharmacological activity (sleeping time). Reversal of barbiturate induced sleeping time suggests hepatoprotective effect of A. scoparia [18]. A. scoparia also has a potent choleretic activity as evident from significant increase in bile volume, bile acid, and bile salt [21]. Recent pharmacological studies also showed anti-inflammatory [22] and antioxidant [23] activities of $A$. scoparia which may contribute to its hepatoprotective activity. Although the plant is recognised as antihelmintic, its mammalian toxicity is negligible [24]. Some cases of dermatitis and allergic reaction have been reported [25]. Phytochemical studies on aerial part of $A$. scoparia showed the presence of hyperin, eupafolin, pedalitin, $5,7,2^{\prime}, 4^{\prime}$-tetrahydroxy-6,5' -dimethoxyflavone, camphor, 1,8-, beta-caryophyllene, cirsilineol, cirsimaritin, arcapillin, and cirsiliol [26].

3.3. Bacopa monnieri Linn. Bacopa monnieri Linn. (family: Plantaginaceae) locally known as "Farfakh" is a small creeping glabrous perennial herb. In Saudi Arabia the plant grows in Tabuk, Al Jauf, Sakakah, northern Hejaz, and eastern region [6]. B. monnieri is largely treasured as a revitalizing herb. In traditional medicine it has been used for more than 3000 years for the treatment of jaundice, liver diseases, spleen disorders, and digestive problems [27, 28].

Hepatoprotective activity of ethanolic extract of whole plant of $B$. monnieri has been studied against nitrobenzene [29] and morphine [30] induced liver toxicity. The extract significantly attenuated hepatotoxin induced changes in biochemical parameters (sera AST, ALT, and APT) and histopathological changes in liver tissues. Ethanolic extract of $B$. monnieri also showed significant antioxidant [30] and anti-inflammatory [31] activities, which may contribute to its hepatoprotective activity. Acute toxicity studies showed no deterious effect in pharmacological doses. The single dose $\mathrm{LD}_{50}$ was found to be $2400 \mathrm{mg} / \mathrm{kg}$ b.w. in rats. In a chronic toxicity study in rats, B. monnieri was found to be well tolerated up to the dose of $500 \mathrm{mg} / \mathrm{kg}$ b.w. for 3 months [32]. Phytochemical analysis on plant of $B$. monnieri showed the presence of alkaloid (brahmine), bacosides, nicotine, herpestine, D-mannitol, hersaponin, stigmosterol, beta-sitosterol, and bacosaponins [30, 33]. Bacoside, a major constituent of brahmi, has been shown to possess significant anticancer activity against liver tumors in rats [34].

3.4. Balanites aegyptiaca Linn. Balanites aegyptiaca Linn. (family: Zygophyllaceae) locally known as "Sidrul Kajjab" is a small shrub with thorn on stem. In Saudi Arabia, it is abundant in southern part of Hejaz ranging from Jeddah to Yemen border [6]. The bark, unripe fruits, and leaves of the B. aegyptiaca are used in folk medicine for the treatment of jaundice, liver disorders, and spleen problems [35].

The effect of ethanolic extracts of bark of $B$. aegyptiaca has been investigated against paracetamol [36] and $\mathrm{CCl}_{4}$ [37] induced hepatotoxicity in rats. The extract dose dependently 
TABLE 1: Saudi herbal drug with hepatoprotective activity.

\begin{tabular}{|c|c|c|c|}
\hline Plant name & Traditional uses & Chemical constituent & Reference \\
\hline Apium graveolens & $\begin{array}{l}\text { Liver and spleen disorders, jaundice, rheumatism, } \\
\text { gout, and inflammatory diseases }\end{array}$ & $\begin{array}{l}\text { Limonene, } \mathrm{p} \text {-dimethyl styrene, } \mathrm{n} \text {-pertyl benzene, } \\
\text { caryophyllene, a-selinene, n-butyl phthalide, and } \\
\text { sedanenolide }\end{array}$ & {$[7-9,13]$} \\
\hline Artemisia scoparia & Jaundice and liver disorders & $\begin{array}{l}\text { Hyperin, eupafolin, pedalitin, } \\
5,7,2^{\prime}, 4^{\prime} \text {-tetrahydroxy- } 6,5^{\prime} \text {-dimethoxyflavone, } \\
\text { camphor, and 1,8-, and beta-caryophyllene }\end{array}$ & {$[16,17,26]$} \\
\hline Bacopa monnieri & $\begin{array}{l}\text { Jaundice, liver diseases, spleen disorders, and } \\
\text { digestive problems }\end{array}$ & $\begin{array}{l}\text { Brahmine, bacosides-a, nicotine, herpestine, } \\
\text { d-mannitol, and hersaponin }\end{array}$ & {$[27,28,34]$} \\
\hline Balanites aegyptiaca & Jaundice, liver disorders, and spleen problems & $\begin{array}{l}\text { Quercetin 3-glucoside, quercetin-3-rutinoside; } \\
\text { 3-glucoside, 3-rutinoside, 3-7-diglucoside, and } \\
\text { 3-rhamnogalactoside }\end{array}$ & {$[35,41]$} \\
\hline Beta vulgaris & $\begin{array}{l}\text { Spleen, liver problems, and inflammatory } \\
\text { disorders }\end{array}$ & $\begin{array}{l}\text { Betacyanins, betaxanthins, oxalic acid, and } \\
\text { ascorbic acid }\end{array}$ & {$[42-44,47]$} \\
\hline Boerhavia diffusa & $\begin{array}{l}\text { Jaundice and other liver diseases, internal } \\
\text { inflammation, gall bladder problem, and spleen } \\
\text { disorders }\end{array}$ & $\begin{array}{l}\text { Punarnavine, boeravinones, flavonoids, amino } \\
\text { acids, lignans, and tetracosanoic, esacosanoic, } \\
\text { stearic, and ursolic acids }\end{array}$ & {$[48]$} \\
\hline Camellia sinensis & $\begin{array}{l}\text { Obesity/weight loss, arthritis, and other } \\
\text { inflammatory conditions }\end{array}$ & Caffeine, theophylline, and theobromine & {$[54,62]$} \\
\hline Clitoria ternatea & Liver diseases & $\begin{array}{l}\text { Taraxerol, taraxerone, ternatins, flavonoids, } \\
\text { saponins, and tannins }\end{array}$ & {$[63,64,66,69]$} \\
\hline $\begin{array}{l}\text { Commiphora } \\
\text { opobalsamum }\end{array}$ & $\begin{array}{l}\text { Stomach, jaundice, liver diseases, joint pain, and } \\
\text { inflammatory disorders }\end{array}$ & $\begin{array}{l}\text { Flavonoids, saponins, volatile oil, sterol, and/or } \\
\text { triterpenes }\end{array}$ & {$[72,73]$} \\
\hline Curcuma longa & $\begin{array}{l}\text { Loss of appetite, jaundice, liver problems, gall } \\
\text { bladder disorders, and arthritis }\end{array}$ & $\begin{array}{l}\text { Curcumin, demethoxycurcumin, and } \\
\text { bis-demethoxycurcumin }\end{array}$ & {$[76-78]$} \\
\hline Eruca sativa & General tonic, liver, and intestinal disorders & Glucosinolates, quercetin, and erucic acid & {$[82-84,86]$} \\
\hline Ficus carica & $\begin{array}{l}\text { Liver disease, stomach ailments, digestive } \\
\text { problems, obesity, and inflammatory diseases }\end{array}$ & $\begin{array}{l}\text { Psoralen, mucilages, flavonoids, vitamins, } \\
\text { nicotinic acid, tyrosine, ficusin, bergaptene, } \\
\text { stigmasterol, taraxasterol, beta-sitosterol, rutin, } \\
\text { and sapogenin }\end{array}$ & {$[89-93,97]$} \\
\hline Grewia mollis & $\begin{array}{l}\text { Liver disease, abdominal problems, arthritis, and } \\
\text { inflammatory conditions }\end{array}$ & $\begin{array}{l}\text { Luteolin, tetrahydroxyflavone, } \\
7 \beta \text {-hydroxy-23-enedeoxojessic acid, } \\
7 \beta \text {-hydroxy-23-deoxojessic acid, } \beta \text {-sitosterol, and } \\
\beta \text {-sitosterol-3-o-glucoside }\end{array}$ & {$[99-102]$} \\
\hline Grewia tenax & $\begin{array}{l}\text { Liver disorders, jaundice, and inflammatory } \\
\text { condition }\end{array}$ & $\begin{array}{l}\text { Betulin, triacontan-1-ol, } \alpha \text {-amyrin, } \beta \text {-amyrin, } \\
\beta \text {-sitosterol, lupenne, erythrodiol, and } \\
\text { tetratriacont-21-ol-12-one }\end{array}$ & {$[4,104,105]$} \\
\hline $\begin{array}{l}\text { Haloxylon } \\
\text { salicornicum }\end{array}$ & $\begin{array}{l}\text { Jaundice, gall bladder stones, liver diseases, } \\
\text { digestive disorders, inflammatory disorder, and } \\
\text { joint diseases }\end{array}$ & $\begin{array}{l}\text { Ursolic acid, } 7 \text {-hydroxy-4-triacontanone, } \\
\text { 24-hydroxy-4-octacosanone, } 1 \text {-triacontanol, } \\
\beta \text {-amyrin, } 24 \text {-ethylcholesta-3,5-diene, } \\
24 \text {-nor-12-ursene, } \beta \text {-sitosterol, and } \beta \text {-sitosterol }\end{array}$ & [106-111] \\
\hline $\begin{array}{l}\text { Hypericum } \\
\text { perforatum }\end{array}$ & $\begin{array}{l}\text { Jaundice, liver diseases, gall bladder stones, } \\
\text { rheumatoid arthritis, and inflammatory } \\
\text { conditions }\end{array}$ & $\begin{array}{l}\text { Rutin, hypericin, pseudohypericin, hyperforin, } \\
\text { adhyperforin, quercetin, hyperoside, campferol, } \\
\text { myricetin, amentoflavone, i3, kielcorin, and } \\
\text { norathyriol }\end{array}$ & [112-115] \\
\hline Juniperus procera & $\begin{array}{l}\text { Liver disease, jaundice, digestive problems, } \\
\text { inflammatory diseases, and ulcers }\end{array}$ & $\begin{array}{l}\beta \text {-peltatin a, methyl ether and } \\
\text { deoxypodophyllotoxin, and totarol }\end{array}$ & [115-117] \\
\hline Lepidium sativum & $\begin{array}{l}\text { Jaundice, liver problems, spleen diseases, } \\
\text { gastrointestinal disorders, arthritis, and } \\
\text { inflammatory disorders }\end{array}$ & $\begin{array}{l}\text { Alkaloids, saponins, anthracene glycosides, } \\
\text { carbohydrates, proteins, amino acids, flavonoids, } \\
\text { and sterols }\end{array}$ & {$[53,118]$} \\
\hline $\begin{array}{l}\text { Moringa oleifera } \\
\text { (seed oil) }\end{array}$ & $\begin{array}{l}\text { Liver disease, lipid disorders, arthritis, and } \\
\text { inflammatory disorders }\end{array}$ & $\beta$-carotene, protein, and vitamin $\mathrm{c}$ & [119-122] \\
\hline Nigella sativa & $\begin{array}{l}\text { Liver tonics, digestive, anti-inflammatory, } \\
\text { immunostimulant, and remedy for jaundice }\end{array}$ & $\begin{array}{l}\text { Thymoquinone, thymohydro quinine, } \\
\text { dithymoquinone, p-cymene, carvacrol, and } \\
\text { 4-terpineol }\end{array}$ & [123-125] \\
\hline Peganum harmala & $\begin{array}{l}\text { Jaundice, digestive disorders, liver disease, and } \\
\text { arthritis }\end{array}$ & $\begin{array}{l}\text { Harmaline, harmine, harmalol, and } \\
\text { tetrahydroharmine }\end{array}$ & [126-131] \\
\hline
\end{tabular}


TABle 1: Continued.

\begin{tabular}{|c|c|c|c|}
\hline Plant name & Traditional uses & Chemical constituent & Reference \\
\hline Pergularia daemia & $\begin{array}{l}\text { Jaundice, liver diseases and inflammatory } \\
\text { disorders }\end{array}$ & $\begin{array}{l}\text { Cardenolides, alkaloid, saponins, triterpenes, and } \\
\text { steroidal compounds }\end{array}$ & {$[132-135]$} \\
\hline Petroselinum crispum & $\begin{array}{l}\text { Liver diseases, constipation, flatulence, jaundice, } \\
\text { colic pain and rheumatism }\end{array}$ & Flavone glycosides & {$[136-140]$} \\
\hline $\begin{array}{l}\text { Phyllanthus } \\
\text { maderaspatensis }\end{array}$ & $\begin{array}{l}\text { Emetic and purgative, constipation, digestion and } \\
\text { abdominal pain liver disorders, rheumatism and } \\
\text { inflammatory diseases }\end{array}$ & Essential oil, mandarin, mucilage, and $\beta$-sitosterol & [141-144] \\
\hline Pimpinella anisum & $\begin{array}{l}\text { Digestive, carminative, antispasmodic and for } \\
\text { liver disorders }\end{array}$ & Trans-anethole and palmitic and oleic acids & [145-147] \\
\hline Portulaca oleracea & $\begin{array}{l}\text { Liver disorders, gastrointestinal problems and } \\
\text { inflammatory disorders }\end{array}$ & $\begin{array}{l}\text { Omega-3 fatty acids, alpha-linolenic acid, and } \\
\text { vitamins a, b, and c }\end{array}$ & {$[82,148-151]$} \\
\hline Rhazya stricta & $\begin{array}{l}\text { Stomach problems, liver diseases and } \\
\text { inflammatory disorders }\end{array}$ & Akuammidine, bhimberine, rhazimol & {$[36,152-155]$} \\
\hline Smilax regelii & $\begin{array}{l}\text { Liver diseases, arthritis and inflammatory } \\
\text { conditions }\end{array}$ & $\begin{array}{l}\text { Saponins flavonoids, tannins, sterols, and } \\
\text { triterpenes }\end{array}$ & {$[156-160]$} \\
\hline Solanum nigrum & $\begin{array}{l}\text { Liver disorders, jaundice and cirrhosis, } \\
\text { inflammatory disorders, rheumatism and swellen } \\
\text { joints }\end{array}$ & $\begin{array}{l}\text { Glycoalkaloids, glycoproteins, polysaccharides, } \\
\text { gallic acid, catechin, protocatechuic acid, caffeic } \\
\text { acid, epicatechin, rutin, and naringenin. }\end{array}$ & {$[161-165]$} \\
\hline Suaeda maritima & Liver, heart and lipid disorders & Alkaloid, flavonoid, and tannins & {$[166-168]$} \\
\hline Tamarix nilotica & Liver, stomach and inflammatory problems & $\begin{array}{l}\text { Kaempferol, syringaresinol, isoferulic acid, } \\
\text { niloticol, 3-hydroxy-4-methoxycinnamaldehyde, } \\
\text { methyl and ethyl esters of gallic acid, } \\
\text { para-methoxygallic acid, quercetin } \\
\text { 3-oglucuronides, 3-o-sulphated kaempferol, and } \\
\text { 7, } 4^{\prime} \text {-dimethyl ether }\end{array}$ & {$[169-171]$} \\
\hline Tephrosia purpurea & $\begin{array}{l}\text { Jaundice, liver, biliary and splenic disease, and } \\
\text { inflammatory disorders }\end{array}$ & $\begin{array}{l}\beta \text {-sitosterol, quercetin, lupeol, rutin, delphinidin } \\
\text { chloride, cyanidin chloride, isolonchocarpin, } \\
\text { lanceolatins a and b, pongamol, karangin, } \\
\text { kangone, 5,7-dimethoxy-8-flavanone, } \\
\text { 2-methoxy-3,9-dihydroxycoumestone }\end{array}$ & {$[172-176]$} \\
\hline Teucrium polium & $\begin{array}{l}\text { Liver diseases, inflammatory disorders, stomach } \\
\text { and intestinal troubles and rheumatism }\end{array}$ & $\begin{array}{l}\text { Caryophyllene, cedrol, a-epi-cadinol, and } \\
\text { e-g-bisabolol }\end{array}$ & {$[177-181]$} \\
\hline $\begin{array}{l}\text { Trianthema } \\
\text { Portulacastrum }\end{array}$ & Liver diseases and pain & $\begin{array}{l}\text { Flavonoid, steroids, fats, terpenes, carbohydrates, } \\
\text { tannins, and alkaloids }\end{array}$ & {$[182,183]$} \\
\hline Tribulus terrestris & Tonic, diuretic, and aphrodisiac & $\begin{array}{l}\text { Tigogenin, neotigogenin, terrestrosid F, and } \\
\text { gitonin }\end{array}$ & {$[184,185]$} \\
\hline
\end{tabular}

attenuated the hepatotoxin induced biochemical (serum AST, ALT, ALP, and bilirubin) and histopathological changes in liver which was comparable with silymarin. The extract also reversed toxin induced prolongation of pentobarbital sleeping time in rats. The purified fractions of B. aegyptiaca possess significant antioxidant [38] and anti-inflammatory [39] activities which may contribute to its hepatoprotective action. Administration of $5 \%$ seed oil in diet produced mild toxicity in rats [40]. Phytochemical studies on B. aegyptiaca showed the presence of flavonoids, saponins, quercetin 3glucoside, quercetin-3-rutinoside, 3-glucoside, 3-rutinoside, 3-7-diglucoside, and 3-rhamnoglucoside [41].

3.5. Beta vulgaris Linn. Beta vulgaris Linn. (family: Amaranthaceae) locally known as "shahya" is an annual or biennial herb found mostly in North Hejaz and Eastern Najd region of Saudi Arabia [6]. Beta vulgaris is extensively cultivated as an article of food and the roots are used for the production of sugar. The plant root has been used in traditional medicine for a wide range of diseases including spleen and liver problems and inflammatory disorders [42-44].

Oral administration of the ethanolic extract of Beta vulgaris roots exhibited significant and dose dependent hepatoprotective activity against $\mathrm{CCl}_{4}$ induced liver damage in rats [45]. The hepatoprotective activity of Beta vulgaris may be attributed to its antioxidant [46] and anti-inflammatory [14] activities. The plant is safe to use even in large doses. Phytochemical studies on roots of Beta vulgaris Linn. have shown the presence of betaine, betacyanins, betaxanthins, oxalic acid, and ascorbic acid [47].

3.6. Boerhavia diffusa Linn. Boerhavia diffusa Linn. (family: Nyctaginaceae) locally known as "maddad" is a tall glabrous plant with a forked herbaceous stem widely distributed in Abha, Bisha, Najran, and Hejaz region of Saudi Arabia [6]. Boerhavia diffusa has been widely used in traditional system 
of medicine for the treatment of jaundice and other liver diseases, internal inflammation, gall bladder problem, and spleen disorders [48].

Aqueous and ethanolic extracts of $B$. diffusa significantly attenuated acetaminophen [49] and ethanol [50] induced biochemical (rise of serum AST, ALT, APT, and bilirubin) and histopathological changes in liver suggesting its hepatoprotective action. The extract has been shown to possess significant antioxidant [49] and anti-inflammatory [51] activities which may contribute to its hepatoprotective activity. The oral $\mathrm{LD}_{50}$ for $B$. diffusa leaves in mice and rats was found to be $2000 \mathrm{mg} / \mathrm{kg}$ b.w. [52]. The aerial part of B. diffusa is a rich source of flavonoids, steroids, and alkaloids. Detailed phytochemical analysis showed the presence of campesterol, daucosterol, sitosterols, punarnavine, boeravinones A-F, borhavone, amino acids, lignans, and tetracosanoic, esacosanoic, stearic, and ursolic acids [48].

3.7. Camellia sinensis Linn. Camellia sinensis Linn. (family: Theaceae) locally known as "Shai." The leaves and buds of this plant are used to produce the popular tea beverage. Our survey showed that Camellia sinensis is the second most commonly used herb by Saudi population for liver problems [53]. The decoction is used for obesity/weight loss, arthritis, and other inflammatory conditions and as anticancer [54].

The hepatoprotective activity of the aqueous extract of C. sinensis has been studied against experimentally induced liver damage in rats. The extract significantly attenuated $\mathrm{CCl}_{4}$ induced biochemical (serum ALT, AST, ALP, total protein, and albumin) and histopathological changes in liver [55]. Tea decoction has been shown to possess significant antioxidant, anti-inflammatory, and immunomodulatory activities [56, 57], which may contribute to its hepatoprotective activity. The antioxidant and anti-inflammatory activity of tea has been attributed to saponin contents of C. sinensis [58]. High doses of tea may cause convulsion/stimulation of central nervous system (CNS) due to its caffeine contents [59]. Some cases of green tea induced liver toxicity have been reported $[60,61]$. Phytochemical studies on aerial part of C. sinensis have shown the presence of saponins, flavonoids, quercetine, quercitrin, rutin, catechin, caffeine, theophylline, and theobromine [62].

3.8. Clitoria ternatea Linn. Clitoria ternatea Linn. (family: Fabaceae) locally known as "Al-clitoria" is a perennial plant with big 5-7 elliptic to lanceolate leaflets abundant in southern Hejaz region of Saudi Arabia [6]. The leaves, seeds, and flowers are used in traditional medicine for liver diseases $[63,64]$.

Methanolic extract of C. ternatea $(200 \mathrm{mg} / \mathrm{kg})$ significantly attenuated $\mathrm{CCl}_{4}$ [65] and paracetamol [66] induced biochemical (serum ALT, AST, and bilirubin levels) and histopathological alterations in liver. "Ayush-Liv.04" a polyherbal formulation consisting of $20 \%$ C. ternatea leaves as one of its constituents also showed significant hepatoprotective activity against ethanol and $\mathrm{CCl}_{4}$ induced liver damage in rats [67]. C. ternatea possess significant anti-inflammatory [68] and antioxidant $[69,70]$ activities which may contribute to its hepatoprotective effects. Roots of $C$. ternatea did not show any toxicological signs or deaths up to doses of $3000 \mathrm{mg} / \mathrm{kg}$ b.w. [71]. Phytochemical studies on leaves of C. ternatea showed the presence of flavonoids, saponins, tannins, glycosides, quercetin, steroids, taraxerol, taraxerone, ternatins, and taraxerol $[66,69]$.

3.9. Commiphora opobalsamum Linn. Commiphora opobalsamum Linn. (family: Burseraceae) locally known as Oode-Balsan, Behsan, or Balessan is medicinal plant with small, thorny tree which grows widely in Mecca region of Saudi Arabia. Local folk healer uses it for the treatment of stomach, jaundice and liver diseases, joint pain, and inflammatory disorders $[72,73]$.

The hepatoprotective activity of ethanolic extract of $C$. opobalsamum was studied using an experimental model of hepatotoxicity in rats [72]. The extract dose dependently protected liver against $\mathrm{CCl}_{4}$ induced biochemical (serum AST, ALT, and APT) and prolongation of the barbiturate sleeping time. The extract also showed significant antioxidant [72] and anti-inflammatory [74] activities which may contribute to its hepatoprotective effects. Even the large doses of ethanolic extract of C. opobalsamum did not show adverse effects in rats [75]. Phytochemical studies on aerial part of C. opobalsamum showed the presence of saponins, volatile oil, sterol and/or triterpenes, friedelin, flavonoids, mearnsetin, and quercetin [72].

3.10. Curcuma longa Linn. Curcuma longa Linn. (family: Zingiberaceae) locally known as "curcum" is a small rhizomatous perennial herb [6]. The genus named Curcuma is the latinized form of the Arabic Al-Kurkum. For over 4000 years, it has been widely used in Asian traditional medicine for loss of appetite, jaundice, liver problems, gall bladder disorders, and arthritis [76, 77]. Experimental studies have substantiated its use as hepatoprotective and hypolipidemic [78].

Hepatoprotective effect of turmeric has been attributed to its antioxidant [79] and anti-inflammatory [80] properties. Sodium curcuminate, a salt of curcumin, also exerts choleretic effects by increasing biliary excretion of bile salts, cholesterol, and bilirubin, supporting its use for the treatment of cholelithiasis. Toxicity studies on C. longa in animals showed no adverse effect up to $2.5 \mathrm{~g} / \mathrm{kg}$ b.w. [81]. In humans, large doses may cause gastric irritation. The healing effect of C. longa is attributed to polyphenolic curcuminoids including curcumin I, curcumin II, and curcumin III [78].

3.11. Eruca sativa Mill. Eruca sativa Mill. (family: Cruciferae) locally known as "Jarjeer" is a hairy plant having oblong leaves grows in northern Hejaz, Najd, and eastern region of Saudi Arabia [6]. In Greeko-Arab medicine, E. sativa is considered as general tonic [82]. It has been used for treatment of liver and intestinal disorders [83]. E. sativa has gained greater importance as a salad vegetable and spice, especially among Middle Eastern populations and Europeans. The leaves and seeds have been investigated for their hepatoprotective, antiinflammatory, and antioxidant activities [84].

The ethanolic extract of $E$. sativa leaves and seeds showed significant hepatoprotective activity against $\mathrm{CCl}_{4}[84]$ and ethanol [85] induced liver injury. The E. Sativa extract also showed significant cytoprotective effect against liver cancer 
cells [86]. The hepatoprotective activity of E. Sativa may be attributed to its antioxidant [87] and anti-inflammatory [88] activities. It is an edible plant with no reported toxicity. Phytochemical studies on leaves of $E$. sativa have shown the presence of large amount of polyphenols, flavonoids, erucin, erysolin, glucosinolates, quercetins, erucic acid, and phenylethyl isothiocyanate $[84,86]$.

3.12. Ficus carica Linn. Ficus carica Linn. (family: Moraceae) locally known as "Hammat teen" is a shrub with milky big palmately lobed leaves found mostly in southern Hejaz and Najd region of Saudi Arabia [6]. The fig is cultivated as an edible fruit. The plant has been widely used in Greeko-Arab traditional medicine for the treatment of liver diseases, stomach ailments, digestive problems, obesity, and inflammatory disorders [89-92].

The hepatoprotective activity of various extracts of $F$. carica leaves and fruits have been experimentally confirmed against $\mathrm{CCl}_{4}[93,94]$ and rifampicin [95] induced hepatotoxicity. The hepatoprotective activity of F. carica may be attributed to its marked anti-inflammatory [96] and antioxidant [97] activities. F. carica being an edible fruit is generally considered safe; however the unripe fruit may cause toxic effect and its sap may cause contact dermatitis [98]. Phytochemical studies on leaves and fruits of $F$. carica have shown the presence of flavonoids, vitamins, nicotinic acid, tyrosine, ficusin, bergaptene, stigmasterol, furocoumarin, psoralen, taraxasterol, beta-sitosterol, rutin, and sapogenin [93, 97].

3.13. Grewia mollis Juss. Grewia mollis Juss. (family: Malvaceae) locally known as "Nab'aa" is a shrub/tree found mostly in Hejaz region of Saudi Arabia [6]. The leaves and bark of G. mollis have been used in traditional medicine for the treatment of liver diseases, abdominal problems, arthritis, and inflammatory conditions [99-101].

Methanolic extract of G. mollis leaves showed significant hepatoprotective activity against $\mathrm{CCl}_{4}$ induced liver injury [102]. G. Mollis extract possesses significant antioxidant [102] and anti-inflammatory [99] activities which may contribute to its hepatoprotective effects. The pharmacological effect of G. mollis may be attributed to its steroidal and/or triterpenoidal constituent which have proven to be anti-inflammatory activity [99]. High doses of G. mollis stem bark may cause mild adverse effects including impairment of liver function [103]. Phytochemical studies on leaves of G. mollis has shown the presence of luteolin, tetrahydroxyflavone, $7 \beta$ hydroxy-23-enedeoxojessic acid, $7 \beta$-hydroxy-23-deoxojessic acid, $\beta$-sitosterol, and $\beta$-sitosterol-3-O-glucoside $[99,102]$.

3.14. Grewia tenax Forsk. Grewia tenax Forsk. (family: Malvaceae) locally known as "khaddar/shohat" is a glabrous shrub found in southern Hejaz region of Saudi Arabia [6]. In traditional medicine leaves, root, and fruits of G. tenax are used for the treatment of digestive diseases, liver disorders, jaundice, and inflammatory conditions $[4,104]$.

The administration of ethanol extract of $G$. tenax significantly restored $\mathrm{CCl}_{4}$ induced biochemical (serum AST, ALT, APT, TB, and gamma-glutamyl transferase) and histopathological changes in rats. Reversal of pentobarbital-induced prolongation of narcolepsy by the extract also suggested its hepatoprotective effect. The chronic administration of extract significantly reduced cholesterol, low-density lipoproteins, and triglycerides level [105]. The hepatoprotective effect of $G$. tenax is attributed to antioxidant [105] and anti-inflammatory $[105,186]$ properties. Experimental studies in mice showed no adverse effect except mild diarrhea in the high dose of $2 \mathrm{~g} / \mathrm{kg}$ b.w. of ethanolic extract [105]. Phytochemical studies on plant of G. tenax have shown the presence of triacontan1-ol, $\alpha$-amyrin, $\beta$-amyrin, $\beta$-Sitosterol, lupenne, erythrodiol, betulin, and tetratriacont-21-ol-12-one $[4,105]$.

\subsection{Haloxylon salicornicum Moq. Haloxylon salicornicum} Moq. (family: Chenopodiaceae) locally known as "Armas" is a stout herb with green succulent branches distributed in all the regions of Saudi Arabia [6]. In Arabian Peninsula and other Asian countries $H$. salicornicum has been used for the treatment of jaundice, gall bladder stones, liver diseases, digestive problems, inflammatory disorder, and joint diseases [106108]. Experimental studies confirmed hepatoprotective [109], anti-inflammatory [110, 187], and antiulcer [107] activity of $H$. salicornicum.

The ethanolic extract of H. salicornicum dose dependently attenuated $\mathrm{CCl}_{4}$ induced increase in liver enzymes and histological changes [109]. Recently Alqasoumi et al. [110] reported antioxidant and anti-inflammatory activities of $H$. salicornicum which may contribute to its hepatoprotective activity. The toxicity studies on $H$. salicornicum extract showed that, even in the high dose of $4 \mathrm{~g} / \mathrm{kg}$ b.w., the extract did not produce any symptoms of toxicity or death in rats $[110,188]$. Phytochemical studies on aerial part of $H$. salicornicum has shown the presence of alkaloids, tannins, saponin glycosides, 7-hydroxy-4-triacontanone, 24-hydroxy4-octacosanone, 1-triacontanol, $\beta$-amyrin, 24-ethylcholesta3,5-diene, 24 -nor-12-ursene, $\beta$-sitosterol, ursolic acid, and $\beta$ sitosterol [109-111].

3.16. Hypericum perforatum Linn. Hypericum perforatum Linn. (family: Hypericaceae) locally known as "Ashba berfortum" is perennial herbs/shrubs with yellow flower. It is popularly known as St John's wart. It is found in southern region of Saudi Arabia [6]. The medicinal use of herbs is mentioned in the writing of famous Greeco-Arab physicians Istikoglou et al. [189]. Avicina, a famous Arab physician in his book "Canon of medicine" ("Al-Quanoon fil Tib" in Arabic), also described medicinal properties of this herb [190]. The traditional medicinal uses of $H$. perforatum include treatment of jaundice, liver diseases, gall bladder stones, rheumatoid arthritis, and other inflammatory conditions [112-114].

Ozturk et al. [113] reported the hepatoprotective effect of alcoholic extract of aerial part of $H$. perforatum extract. The extract significantly attenuated $\mathrm{CCI}_{4}$ and ethanol $[112,113]$ induced hepatic toxicity. Experimental studies also showed significant choleretic activity of $H$. Perforatum [112]. The protective action of $H$. perforatum has been attributed to its anti-inflammatory [191], antioxidant, and immunomodulating activities [192]. Acute toxicity studies in rodent showed no toxicity; however chronic administration for 2 weeks showed significant signs of erythema, dermal edema, alopecia, and 
changes in blood chemistry. The animals gained less weight as compared to control in chronically treated groups [193]. Phytochemical studies on plant of $H$. perforatum showed the presence of hypericin, pseudohypericin, hyperforin, adhyperforin, quercetin, hyperoside, rutin, campferol, myricetin, amentoflavone, kielcorin, and norathyriol [115].

3.17. Juniperus procera Hochst. ex Endl. Juniperus procera Hochst. ex Endl. (family: Cupressaceae) locally known as "Arar" is a long tree with needle like leaves found in Hejaz and southern region of Saudi Arabia [6]. The plant has long been used in Saudi traditional medicine for liver disease, jaundice, digestive problems, and inflammatory diseases [116]. The resin of $J$. procera in combination with honey is also used as cure for liver diseases and ulcers [115].

The ethanolic extracts of aerial part of J. procera showed significant hepatoprotective activity against $\mathrm{CCl}_{4}$ induced liver injury [117]. The hepatoprotective activity has been attributed to terpene contents of J. procera [116]. J. procera possess significant antioxidant/free radical scavenging [194] and anti-inflammatory activities [195] which may contribute to its hepatoprotective activity. Acute and chronic toxicity studies revealed that the extract of $J$. procera is free from toxicity even in high dose [116]. Phytochemical studies on aerial part of $J$. procera showed the presence of terpenes, $\beta$-peltatin A, deoxypodophyllotoxin, and totarol [117].

3.18. Lepidium sativum Linn. Lepidium sativum Linn. (family: Cruciferae) locally known as "El-Rshad" is a fast-growing, edible herb with tangy flavour and aroma [6]. In traditional system of medicine various parts of plant have been used for the treatment of jaundice, liver problems, spleen diseases, gastrointestinal disorders, arthritis, and other inflammatory conditions $[53,118]$.

Hepatoprotective effect of methanolic extracts of $L$. sativum seeds was evaluated against $\mathrm{CCl}_{4}$ induced liver damage in rats. The extract dose dependently attenuated $\mathrm{CCl}_{4}$ induced rise in serum levels of AST, ALT, APT, and bilirubin suggesting its hepatoprotective activity [196]. Recently $L$. sativum has been shown to possess significant antioxidant [197-199] and anti-inflammatory [200] activities which may contribute to its hepatoprotective effect. In rats, up to $2 \% \mathrm{w} / \mathrm{w}$ of L. sativum in diet did not produce any toxicity, whereas $10 \%$ w/w showed mild toxicity [201]. Phytochemical studies on seed of L. sativum showed the presence of alkaloids, saponins, anthracene glycosides, carbohydrates, proteins, amino acids, flavonoids, and sterols [118].

3.19. Moringa oleifera Lam. Moringa oleifera Lam. (family: Moringaceae) locally known as "Ruwag" is a small, graceful, deciduous tree with sparse foliage [6]. The plant grows abundantly in many tropical and subtropical countries. Moringa is an ancient magic plant with a plethora of medicinal and nutritional value. The leaves, flowers, root, gums, fruit, and seed of $M$. oleifera have been extensively used in traditional medicine for the treatment of liver disease, lipid disorders, arthritis, and other inflammatory disorders [119-122].
Hepatoprotective effect of the ethanolic extract of $M$. oleifera leaves was studied against antitubercular drugs (isoniazid, rifampicin, and pyrazinamide) [202] induced liver damage as well as against cadmium induced hepatotoxicity in rats. Moringa extract significantly attenuated hepatotoxin induced biochemical (serum AST, ALT, APT, and bilirubin) and histopathological changes in liver. The hepatoprotective activity of $M$. oleifera was comparable with silymarin [203]. The extracts of $M$. oleifera leaves also showed significant antioxidant [204] and anti-inflammatory [120, 205] activities which may contribute to its hepatoprotective effect. The aqueous extract of $M$. oleifera is relatively safe with an $\mathrm{LD}_{50}$ value of $5 \mathrm{~g} / \mathrm{kg}$ b.w. in mice [206]. Phytochemical studies of $M$. oleifera showed the presence of alkaloids, anthocyanins, $\beta$ carotene, protein, vitamin $\mathrm{C}$, phenolics, calcium, iron, and potassium [122].

3.20. Nigella sativa Linn. Nigella sativa Linn. (family: Ranunculaceae) locally known as "Habbul-Barka" is a widely used medicinal plant throughout the world. According to Islamic and Arab literature, black seed of $N$. sativa is one of the most powerful herbal drugs used as liver tonics, digestive, antiinflammatory, immunostimulant, and remedy for jaundice $[123,124]$.

Aqueous suspension of seeds powder of $N$. sativa showed significant hepatoprotective activity against $\mathrm{CCl}_{4}$ and ischemic-reperfusion induced liver injury [124, 207-211]. The anti-inflammatory [212-214] immunomodulating [215] antioxidant [216] activities of $N$. sativa may contribute to its hepatoprotective activity. The extracts and oil are relatively safe. The oral $\mathrm{LD}_{50}$ value of $N$. sativa fixed oil was found to be $28.8 \mathrm{~mL} / \mathrm{kg}$ b.w. in mice [217]. Phytochemical studies on plant of $N$. sativa have shown the presence of thymoquinone, thymohydroquinone, dithymoquinone, p-cymene, carvacrol, and 4-terpineol [125].

3.21. Peganum harmala Linn. Peganum harmala Linn. (family: Nitrariaceae) locally known as "Harmal/Naqt" is a glabrous shrub found mostly in northern Hejaz and eastern Najd region of Saudi Arabia [6]. In traditional medicine $P$. harmala has been used for the treatment of jaundice, digestive disorders, liver diseases, and arthritis [126-129].

The hepatoprotective effect of ethanol and chloroform extracts of $P$. harmala seeds has been studied against thiourea [131] and $\mathrm{CCl}_{4}$ induced hepatotoxicity $[218,219]$ in rats. Both extracts dose dependently attenuated hepatotoxin induced biochemical (serum AST, ALT, and bilirubin) and histopathological changes suggesting its hepatoprotective activity. The extract also showed antioxidant [219] and anti-inflammatory [220] activities which may contribute to its hepatoprotective activity. Acute toxicity studies on the aqueous extract of $P$. harmala revealed that large doses may cause reversible tremors and convulsions in rats [221]. Oral $\mathrm{LD}_{50}$ in Wistar rats was found to be $2.70 \mathrm{~g} / \mathrm{kg}$ b.w. In chronic studies aqueous extract of $P$. harmala administered orally for six weeks at doses of $1,1.35$, and $2 \mathrm{~g} / \mathrm{kg}$ b.w. daily for 3-month period increased liver enzyme suggesting its hepatotoxicity. Histologic study also showed liver degeneration and spongiform changes in the central nervous system (CNS) in chronically 
treated rats [222]. Phytochemical studies on plant of $P$. harmala showed the presence of harmaline, harmine, harmalol, and tetrahydroharmine $[130,131,223]$.

3.22. Pergularia daemia Forsk. Pergularia daemia Forsk. (family: Apocynaceae) locally known as "Ghalqa" is a climbing plant with thin glabrous leaves found in Najd region of Saudi Arabia [6]. In traditional system of medicine the whole aerial part of the plant is extensively used for the treatment of jaundice, liver diseases, and inflammatory disorders [132134].

The ethanolic extracts of aerial parts of $P$. daemia dose dependently prevented the paracetamol [133] and $\mathrm{CCl}_{4}[134$, 135] induced biochemical (serum AST, ALT, APT, and TB) and histopathological changes in the liver. Recent studies on $P$. daemia showed significant anti-inflammatory, antioxidant, and free radical scavenging activities [132-134] which may also contribute to its hepatoprotective activity. The ethanolic extract of $P$. daemia is relatively safe as it did not produce any toxicity up to a dose of $1.5 \mathrm{~g} / \mathrm{kg}$ b.w. in mice [224]. Phytochemical studies on $P$. daemia have shown the presence of cardenolides, alkaloids, flavonoids, saponins, triterpenes, and steroidal compounds $[134,135]$.

3.23. Petroselinum crispum Mill. Petroselinum crispum Mill. (family: Umbelliferae) locally known as "Baqdunis" is a biennial herb widely grown in all the regions of Saudi Arabia [6]. P. crispum has been used in Arab traditional medicine, for the treatment of inflammatory condition, liver diseases, constipation, flatulence, jaundice, colic pain, and rheumatism [136, 137].

Ethanolic extract of $P$. crispum leaves has been pharmacologically investigated for its hepatoprotective activity [138]. The extract dose dependently attenuated $\mathrm{CCl}_{4}$ induced increase in serum AST, ALT, ALP, and total bilirubin. The ethanolic extract of $P$. crispum leaves also showed significant anti-inflammatory [138] and antioxidant [225, 226] activities which may contribute to its hepatoprotective action. Although perfectly safe in pharmacological doses, $P$. crispum may be toxic in excess, especially when used as essential oil [227]. Phytochemical studies on P. crispum have showed the presence of flavones glycosides, apigenin-7-O-glucoside or cosmosiin, apigenin-7-O-apiosyl-O-glucoside/apiin, and the coumarin $2^{\prime \prime}, 3^{\prime \prime}$-dihydroxy furanocoumarin/oxypeucedanin hydrate [138-140].

3.24. Phyllanthus maderaspatensis Linn. Phyllanthus maderaspatensis Linn. (family: Euphorbiaceae) locally known as "Damabas" is a small branched shrub with scattered leaves and grows abundantly in eastern Najd and southern Hejaz region of Saudi Arabia [6]. In traditional medicine, sap and leaf decoction have been used as emetic and purgative; decoction of root is used for constipation, digestion, and abdominal pain. The aerial parts of plant have been used for treating liver disorders, rheumatism, and inflammatory diseases [141-143].

The hepatoprotective activity of whole plant extract of $P$. maderaspatensis has been investigated using several experimental models of hepatotoxicity $[142,228]$. The extract significantly attenuated $\mathrm{CCl}_{4}$ induced biochemical (serum AST and ALT) and histopathological changes in liver. The hepatoprotective effect of Phyllanthus was comparable with silymarin [142]. P. maderaspatensis showed strong antioxidant [229] and anti-inflammatory [230] activities which may contribute to its hepatoprotective activity. $P$. maderaspatensis is considered as safe in pharmacological doses [231]. Phytochemical studies on $P$. maderaspatensis showed the presence of carbohydrates, proteins, flavonoids, essential oil, and tannins. Seeds of $P$. maderaspatensis contain long chain fatty acids and $\beta$-sitosterol [142]. Defatted seed cake contains mucilage, which yields galactose, arabinose, rhamnose and aldobionic acid, niruriside, phyllanthin, hypophyllanthin, and cinnamoyl sucrose acetate [144].

3.25. Pimpinella anisum Linn. Pimpinella anisum Linn. (family: Umbelliferae) locally known as "Alyansoon" is one of the oldest known annual medicinal herbs with white flowers and small seeds. In Arab traditional medicine the plant is used as digestive, carminative, antispasmodic, and liver disorders $[145,146]$.

Diethyl ether extract of $P$. anisum seed has been investigated for its hepatoprotective activity in rats. The extract dose dependently attenuated $\mathrm{CCl}_{4}$ induced rise liver enzymes including AST and ALT [232]. P. anisum possess significant antioxidant $[233,234]$ and anti-inflammatory [235] activities which may contribute to its hepatoprotective efficacy. Oral lethal dose of anise oil in human being ranges between 50 and $5000 \mathrm{mg} / \mathrm{kg}$ [236]. Essential oil of P. anisum has an $\mathrm{LD}_{50}$ value of $0.84 \mathrm{~mL} / \mathrm{kg}$ b.w of mice whereas the fixed oil has an $\mathrm{LD}_{50}$ value of $3.15 \mathrm{~mL} / \mathrm{kg}$ in mice [237]. Phytochemical studies on plant of $P$. anisum have shown the presence of volatile oils (anethole, eugenol, methyl chavicol, and estragole), fatty acids (palmitic, petroselinic, vaccenic, and oleic acids), and coumarins [147].

3.26. Portulaca oleracea Linn. Portulaca oleracea Linn. (family: Portulacaceae) locally known as "Rizlah" and "Farfahena" is an annual herb with branched stems found in Hejaz region and eastern part of Saudi Arabia [6]. The medicinal use of $P$. oleracea was known by Arabs from the time of Pharaohs [238]. It is used for the treatment of liver disorders, gastrointestinal problems, and inflammatory condition $[82,148]$.

The hepatoprotective activity of the aqueous and ethanolic extract of $P$. oleracea whole plant has been investigated by several investigators $[148,149,239]$. The extract significantly attenuated $\mathrm{CCl}_{4}$ induced rise in biochemical (serum AST, APT, TB, and total protein) and histopathological changes in liver. It also antagonised $\mathrm{CCl}_{4}$ and prolonged pentobarbitone induced sleeping time clearly suggesting significant hepatoprotective activity. The extracts of $P$. oleracea also showed significant antioxidant [240] and anti-inflammatory [241] activities which may contribute to its hepatoprotective activity. Methanolic extract of $P$. oleracea has an $\mathrm{LD}_{50}$ value of $1.8 \mathrm{~g} / \mathrm{kg}$ b.w. in mice. In high doses the extract may cause kidney, lung, and liver toxicity in a dose dependent manner [242]. $P$. oleracea contains several biologically active compounds that include, alkaloids, coumarins, flavonoids, cardiac glycosides, anthraquinone glycosides, alanine, saponins, tannins, and 
organic acids (free oxalic acids, cinnamic acids, caffeic acid, malic acids, and citric acids). Omega-3-acids, alpha-linolenic acid, vitamins, glutathione, glutamic acid, and aspartic acid containing $\beta$-sitosterol have also been found in various parts of plants [149-151].

3.27. Rhazya stricta Decne. Rhazya stricta Decne. (family: Apocynaceae) locally known as "harmal" is a perennial sand binding under shrub found in all regions of Saudi Arabia [6]. In the honor of Al-Rhazes, a leading scholar and physician of Arab and Islamic world, the plant was named as Rhazya stricta. In traditional medicine the plant is used for the treatment of inflammatory condition, stomach problems, and liver diseases [152-154].

Pretreatment with $R$. stricta significantly protected mice against paracetamol induced biochemical changes and prolongation of pentobarbitone induced sleeping time. The hepatoprotective effect of $R$. stricta was comparable with silymarin [36]. The extract of $R$. stricta leaves also showed significant antioxidant [154] and anti-inflammatory [243] activities which may contribute to its hepatoprotective activity. Ingestion in therapeutic doses is perfectly safe in human; however chronic administration of high doses in rats has shown variety of toxic effects including decrease in growth rate, dullness, and hepatonephrotoxicity $[155,244]$. Phytochemical studies on $R$. stricta showed the presence of alkaloids (rhazimine, stemmadenine, vincadine, and rhazimanine), carboline, and flavonoidal glycoside $[36,154,155]$.

3.28. Smilax regelii Killip and CV Morton. Smilax regelii Killip and CV Morton (family: Liliaceae) locally known as "Nabatul Fusaq" is a perennial, trailing vine with prickly stems [6]. The plant commonly known as sarsaparilla has been widely used for the treatment of liver diseases, arthritis, and other inflammatory conditions and as an immunomodulator in GreekoArab system of medicine [156-158]. Besides its medicinal use, sarsaparilla is often used as a flavouring agent in nonalcoholic drinks [245]. A decoction made from the roots is used as a vehicle in the preparation of syrups which have been reported to have cooling properties [246].

The hepatoprotective effect of the ethanol extract of roots of $S$. regelii has been studied in rats. Ethanolic extract of sarsaparilla significantly inhibited $\mathrm{CCI}_{4}$ induced rise in AST, ALT, and bilirubin, in serum in rats [247]. The extract showed strong antioxidant [247], anti-inflammatory [159], and immunomodulating [248] activities which may contribute to its hepatoprotective property. No known toxicity or side effects have been documented for sarsaparilla; however ingestion of large doses may cause gastric irritation [160]. Phytochemical studies on plant of $S$. regelii showed the presence of cetyl-parigenin, astilbin, beta-sitosterol, caffeoyl-shikimic acids, dihydroquercetin, diosgenin, engeletin, essential oils, epsilon-sitosterol, eucryphin, eurryphin, ferulic acid, glucopyranosides, isoastilbin, isoengetitin, kaempferol, parigenin, parillin, pollinastanol, resveratrol, rhamnose, saponin, sarasaponin, sarsaparilloside, sarsaponin, sarsasapogenin, shikimic acid, sitosterol-d-glucoside, smilagenin, smilasaponin, smilax saponins A-C, smiglaside A-E, smitilbin, stigmasterol and taxifolin, and titogenin $[159,160]$.
3.29. Solanum nigrum Linn. Solanum nigrum Linn. (family: Solanaceae) locally known as "Anaab ud dib" is an annual hairy herb with ovate to oblong leaves abundant in all parts of Saudi Arabia [6]. The plant is a house hold remedy for liver disorders, jaundice and cirrhosis, inflammatory condition, rheumatism, and swollen joints [161-163].

The extracts of whole plant of S. nigrum significantly attenuated $\mathrm{CCl}_{4}[164,165,249-251]$ and thioacetamide [252] induced biochemical (serum AST, ALT, APT, and TB) and histopathological changes in liver. The hepatoprotective action of $S$. nigrum may be attributed to its antioxidant [253] and anti-inflammatory [254] constituents. LD $_{50}$ value of ethanol extract of the fruits of $S$. nigrum in rats was found to be $2 \mathrm{~g} / \mathrm{kg}$ b.w. [255]. Phytochemical studies on S. nigrum showed the presence of glycoalkaloids, glycoproteins, polysaccharides, gallic acid, catechin, protocatechuic acid, caffeic acid, epicatechin, rutin, and naringenin $[164,165]$.

3.30. Suaeda maritima Linn. Suaeda maritima Linn. (family: Amaranthaceae) locally known as "Sawad" is shrubs with continuous unjoined stems found in western region of Saudi Arabia $[6,256]$. The juice of this herb is used for treatment of liver diseases by Arab practitioners [257]. The leaves are also used as remedy for liver, heart, and lipid disorders [166].

The ethanolic extracts of S. maritima leaves significantly attenuated concanavalin (a hepatotoxin) induced biochemical (serum AST, ALT, APT, and bilirubin) and histopathological changes in liver [167]. The extract of plant also showed significant antioxidant, anti-inflammatory, antiviral, and antibacterial activities $[167,168]$ which may contribute to its hepatoprotective activity. It is nontoxic edible plant which is used in salad and as fodder for animals [258]. The $\mathrm{LD}_{50}$ of ethanolic extract of S. maritima in rats was found to be $3 \mathrm{~g} / \mathrm{kg}$ b.w. [167]. Phytochemical studies on plant of S. maritima showed the presence of alkaloid, flavonoid, sterols, phenolic compounds, and tannins [166-168].

3.31. Tamarix nilotica Ehrenb Bunge. Tamarix nilotica Ehrenb Bunge (family: Tamaricaceae) locally known as "Tarafa" is a green shrub with free distinct blade type leaves found in eastern Najd and northern region of Saudi Arabia [6]. Avicenna has mentioned this plant in his famous book "Canon of medicine" for the treatment of liver, stomach, and inflammatory problems [169-171].

The hydroalcoholic extract of T. nilotica flower showed marked hepatoprotective activity against $\mathrm{CCl}_{4}$ induced liver injury [171]. Experimental studies also showed highly significant antioxidant [171] and anti-inflammatory [259] activities of $T$. nilotica which may contribute its hepatoprotective activity. No experimental and clinical toxicity of T. nilotica has been reported. However plant possesses significant cytotoxicity against some human cancer cell lines [170]. Phytochemical studies on T. nilotica showed the presence of flavonoids, tannins, syringaresinol, isoferulic acid, niloticol, 3-hydroxy-4-methoxycinnamaldehyde, methyl and ethyl esters of gallic acid, para-methoxygallic acid, kaempferol, quercetin 3-oglucuronides, 3-o-sulphated kaempferol, 7,4' dimethyl ether, and free flavonols [170, 171]. 


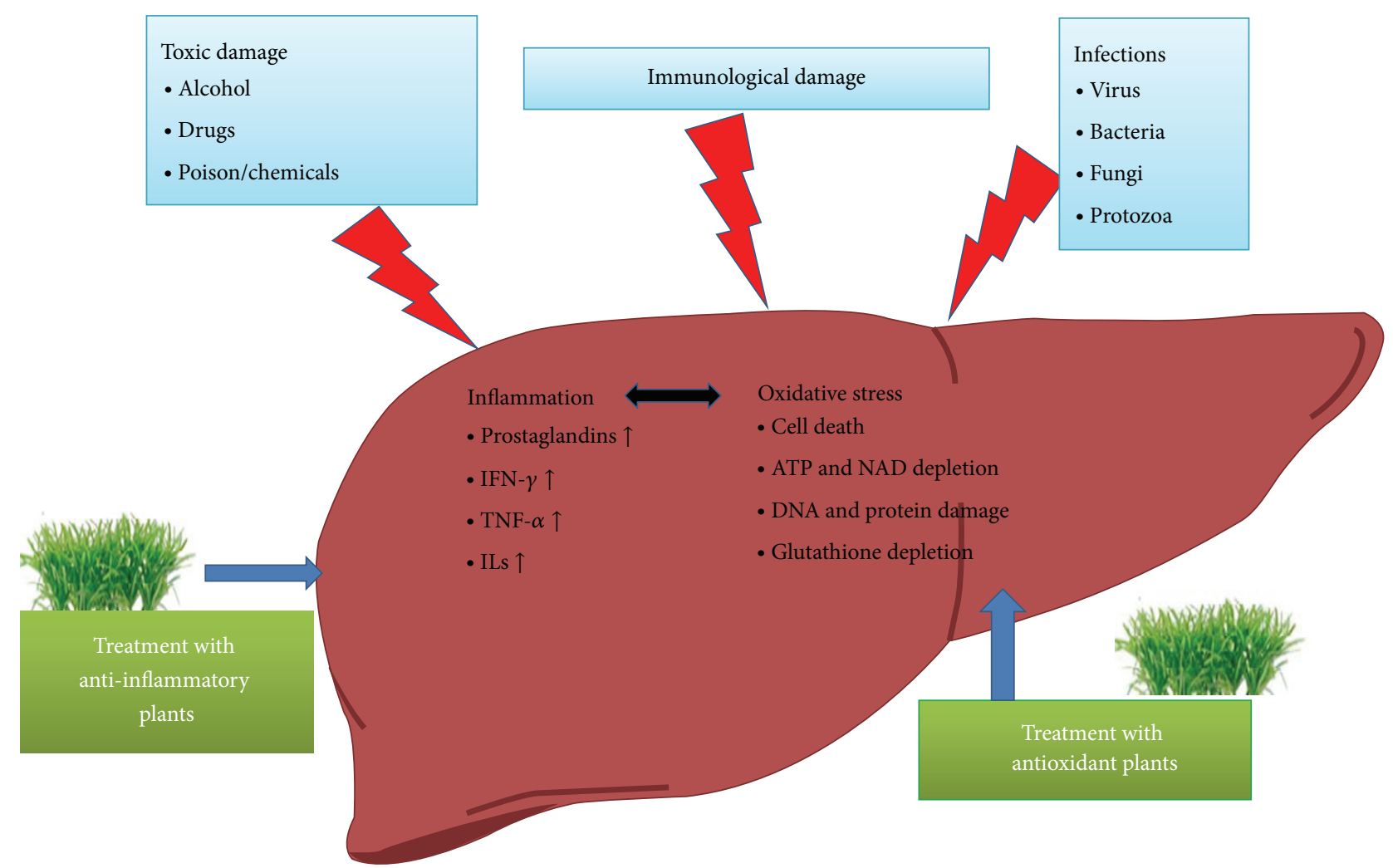

FIGURE 1: Anti-inflammatory and anti-oxidant herbs protect liver against variety of toxins and injurious stimuli by restoring the oxidative stress related liver damage and inflammatory cytokines.

3.32. Tephrosia purpurea Linn. Tephrosia purpurea Linn. (family: Fabaceae) locally known as "Ami" is a perennial plant with imparipinnate leaves and grows in southern Hejaz region of Saudi Arabia [6]. T. purpurea has been used for centuries in traditional system of medicine for the treatment of jaundice, liver, biliary and splenic disease, and inflammatory disorders [172-174].

The hydroalcoholic extract of aerial parts of T. purpurea attenuated thioacetamide [175] induced hepatotoxicity in a dose dependent manner suggesting its significant hepatoprotective activity. The extract also showed antioxidant [175] and anti-inflammatory [260] activities, which may contribute to its hepatoprotective activity. T. purpurea is well tolerated in rats and produces no toxicity up to the dose of $2000 \mathrm{mg} / \mathrm{kg}$ b.w. Chronic administration of T. purpurea at doses of 200 and $400 \mathrm{mg} / \mathrm{kg}$ b.w. was also found safe in rats [261]. Phytochemical studies on T. purpurea have shown the presence of $\beta$-sitosterol, quercetin, lupeol, rutin, delphinidin chloride, cyanidin chloride, isolonchocarpin, lanceolatins $\mathrm{A}$ and $\mathrm{B}$, pongamol, karangin, kangone, 5,7-dimethoxy-8-flavanone, and 2-methoxy-3,9-dihydroxycoumestone [175, 176].

3.33. Teucrium polium Linn. Teucrium polium Linn. (family: Lamiaceae) locally known as "Jaad" is a perennial branched shrub found in northern region, Nefud region, southern Hejaz, East Najd, and eastern province of Saudi Arabia [6]. T. polium is widely used by the folk-medicine practitioners of Saudi Arabia for the treatment of liver diseases, inflammatory disorders, stomach and intestinal troubles, and rheumatism [177].

The hydroalcoholic extract of aerial part of T. polium dose dependently attenuated $\mathrm{CCl}_{4}$ [178] and acetaminophen [262] induced biochemical (serum ALT, AST, APT, and total bilirubin) and histological changes in liver. Experimental studies of $T$. polium on cultured hepatocytes also confirmed its strong antioxidant $[178,263]$ and anti-inflammatory activities $[177,264,265]$ which may contribute to its hepatoprotective activity. There is no report on acute toxicity of plants. However chronic administration of high dose of T. polium rats showed mild toxicity [266]. One case of severe hepatotoxicity has been reported in a patient following prolonged use of T. polium [267, 268]. Phytochemical studies on T. polium showed the presence of flavonoids, terpenes including syrapoline, thujene, caryophyllene, cedrol, epi-cadinol, and bisabolene [178-181].

3.34. Trianthema portulacastrum Linn. T. portulacastrum Linn. (family: Aizoaceae) locally known as "Laani" is a fleshy herb with opposite petiolated unequal leaves found in eastern province and southern Hejaz part of Saudi Arabia [6]. T. portulacastrum is widely used in Arab countries [269], Africa, India, and southeast Asia, for the treatment of jaundice, liver disorders, stomach problem, arthritis, and inflammation [182, $270,271]$. Laboratory investigations on extracts of the plant have demonstrated significant hepatoprotective, antioxidant, diuretic, analgesic, and anticarcinogenic activity [182]. 


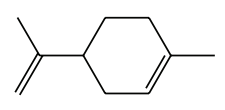

Limonene

(a)

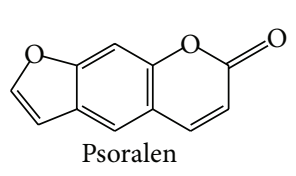

(b)

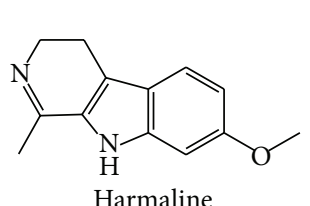

(c)

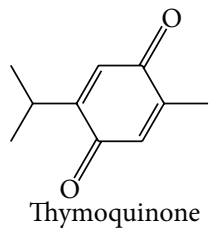

(d)

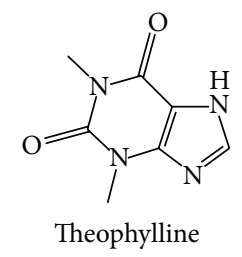

(e)<smiles>CC1=CCC(C(C)(O)CCC=C(C)C(=O)OCc2ccccc2)CC1</smiles>

(f)

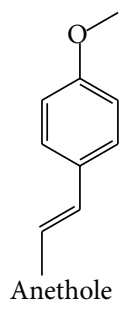

(g)<smiles>COc1cc(/C=C/C(=O)CC(=O)/C=C/c2ccc(O)c(OC)c2)ccc1O</smiles>

(h)<smiles>O=c1c(O)c(-c2ccc(O)c(O)c2)oc2cc(O)cc(O)c12</smiles>

(i)<smiles>O=c1cc(-c2ccc(O)c(O)c2)oc2cc(O)cc(O)c12</smiles>

(j)<smiles>COc1c(-c2ccc(O)c(O)c2)oc2cc(O)cc(O)c2c1=O</smiles>

Hyperin

(k)<smiles>CC1CCC2(OC1)OC1CC3C4CCC5CC(O)CCC5(C)C4CCC3(C)C(C)C1C2C</smiles>

Tigogenin

(n)<smiles>CCCCCC(=O)C1=CC(=CC=[N+]2c3cc(O)c(O[As])cc3CC2C(=O)O)CC(C(=O)O)N1</smiles>

(l)

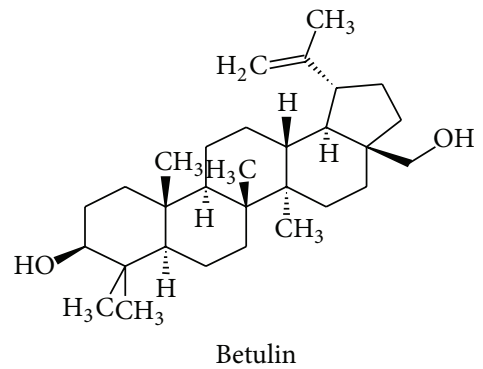

$(\mathrm{m})$<smiles>[R10]O[C@H]1[C@@H](OC[C@H]2O[C@H](Oc3c(-c4ccc(O)c(O)c4)oc4cc(O)cc(O)c4c3=O)[C@H](O)[C@H](O)[C@@H]2O)O[C@H](C)[C@H](O)[C@H]1O</smiles>

(p)

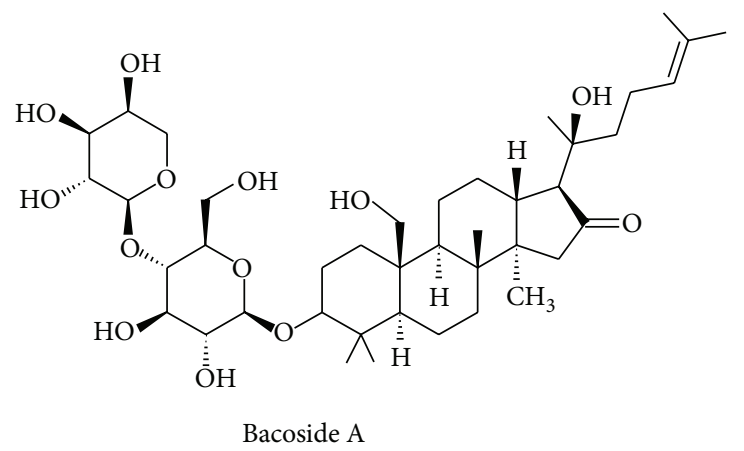

(q)<smiles>CC1(C)CCC2(C)CC=C3C(C)(CCC4C3(C)CCC3C(C)(C)C(O)CCC43C)C2C1</smiles>

Taraxerol

(o)

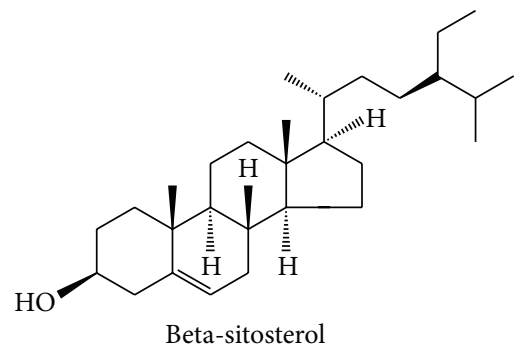

$(\mathrm{r})$

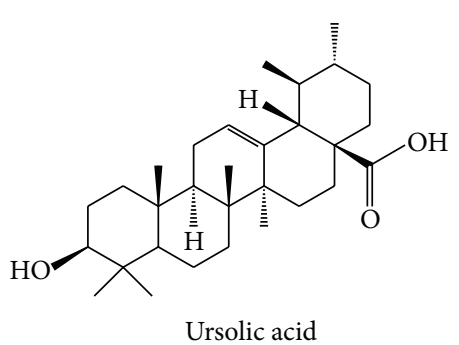

(s)

FIGURE 2: Chemical structure of some of the hepatoprotective phytoconstituents. 
The ethanolic extract of leaves of T. portulacastrum significantly attenuated the paracetamol [272], thioacetamide [272], and aflatoxin B [183] induced hepatotoxicity in experimental studies. The extract of $T$. portulacastrum also showed significant antioxidant $[273,274]$ and anti-inflammatory [275] activities, which may contribute to its hepatoprotective effect. Acute toxicity studies in albino mice suggested that the extract of T. portulacastrum was safe even at the dose of $3 \mathrm{~g} / \mathrm{kg}$ b.w. [276]. Phytochemical studies on T. portulacastrum showed the presence of steroids, saponins, flavonoid, coumarins, terpenes, glycosides, tannins, alkaloids, and volatile oil $[182,183]$.

3.35. Tribulus terrestris Linn. Tribulus terrestris Linn. (family: Zygophyllaceae) locally known as "Darisa" is an annual procumbent herb with compound paripinnate leaves found in eastern Najd and southern Hejaz region of Saudi Arabia [6]. Local bedouin use the plant to treat urinary disorders, impotency, and liver diseases. The seeds of this plant are recommended in hemorrhages, kidney stone, and gout. The fruit is regarded as tonic, diuretic, and aphrodisiac [184].

The aqueous and hydroalcoholic extracts of fruit of $T$. terrestris dose dependently attenuated paracetamol [277] and ferrous sulphate [278] induced liver damage. Two compounds (tribulusamides $\mathrm{A}$ and $\mathrm{B}$ ), isolated from the fruits of $T$. terrestris significantly, protected cultured hepatocytes against $D$-galactosamine induced toxicity [279]. T. terrestris has also been reported to possess antioxidant [280] and antiinflammatory [281] activities which may contribute to its hepatoprotection. According to some reports grazing on $T$. terrestris caused hepatorenal syndrome and neurotoxicity in goats and sheep [282, 283]. Nephrotoxicity has also been reported in patient following chronic use of T. terrestris [284]. The extract also showed antispasmodic activity in rats [285]. Phytochemical studies on T. terrestris showed the presence of Tribulusamides A and B, tigogenin, neotigogenin, terrestrosid F, and gitonin [185].

\section{Conclusion}

Ancient classical literature and ethnomedical survey among local population clearly suggest that herbal drugs have been extensively used in Arab traditional medicine for the treatment of liver diseases. In this review we present the scientific appraisal of 35 herbal drugs used in Saudi traditional medicine for the treatment of liver disorders. The effect of herbs against hepatotoxin induced liver injury (based on biochemical markers and histopathological findings) has been summarized. Besides reviewing hepatoprotective efficacy and possible mechanism of action of these plant drugs, the available data on phytochemical constituents and their toxic untoward effects have been presented. Although the meta-analysis of available scientific literature on hepatoprotective activity of the herbs to a great extent substantiates folkloric claims about the usefulness of these botanicals to treat chronic liver diseases, the data regarding randomized clinical trials, safety studies, and quality control of these herbs is far from satisfactory.
One of the noteworthy findings in this review is that the majority of hepatoprotective plants showed antioxidant and anti-inflammatory activities. The mechanism of hepatic injury invariably involves peroxidation of hepatocyte membrane fatty acids causing destruction of the cells and their intracellular organelles. According to the recent reports oxidative stress plays a pivotal role in the initiation and progression of hepatic damage following insult to a variety of hepatotoxins. The role of oxidative stress in viral hepatitis and autoimmune related liver diseases has been extensively documented. Moreover hepatotoxic chemicals damage liver cells primarily by producing reactive species which form covalent bond with the lipid moiety of the hepatic cell membranes (Figure 1).

Due to extensive exposure to hazardous chemicals, sometimes the free radicals generated are so high that they overpower the natural defensive system leading to hepatic damage. The drugs/chemicals with antioxidant properties such as Vitamin E and silymarin have been shown to protect against toxin induced hepatotoxicity. On the other hand inflammation is a key event in hepatotoxin induced liver damage. The toxins directly or through oxidative stress mechanism may trigger inflammatory response in the liver, which is evident from a significant increase in the proinflammatory cytokines including TNF $\alpha$ and IL6 and hepatocyte inflammation. Majority of hepatoprotective herbs have been shown to suppress oxidative stress and inflammation.

Our survey and published reports clearly suggest that medical plants used in traditional medicine are rich sources of medicinally active chemical constituents such as phenols, coumarins, lignans, terpenoids, carotenoids, glycosides, flavonoids, organic acids, alkaloids, and xanthene. Some of the purified phytomolecules isolated from these plants have also been shown to possess potent hepatoprotective activity (Figure 2).

Further investigation into the lead molecules that may produce better, safe, and effective therapeutic effects is warranted to overcome the pharmaceutical imbalance between remedies that protect the liver and drugs that induce hepatotoxicity. Moreover quality control of herbal drugs and randomized controlled clinical trials will further validate the evidenced based herbal therapy for the treatment of liver diseases.

\section{Conflict of Interests}

The authors declare that there is no conflict of interests regarding the publication of this paper.

\section{References}

[1] B. V. Subbarayappa, "The roots of ancient medicine: an historical outline," Journal of Biosciences, vol. 26, no. 2, pp. 135-143, 2001.

[2] B. Saad, H. Azaizeh, and O. Said, "Arab herbal medicine," in Botanical Medicine in Clinical Practice, vol. 4, pp. 31-39, 2008.

[3] B. Saad, H. Azaizeh, and O. Said, "Tradition and perspectives of Arab herbal medicine: a review," Evidence-Based Complementary and Alternative Medicine, vol. 2, no. 4, pp. 475-479, 2005. 
[4] N. Sharma and V. Patni, "Grewia tenax (Frosk.) Fiori.-a traditional medicinal plant with enormous economic prospectives," Asian Journal of Pharmaceutical and Clinical Research, vol. 5, no. 3, pp. 28-32, 2012.

[5] C. Girish and S. C. Pradhan, "Indian herbal medicines in the treatment of liver diseases: problems and promises," Fundamental and Clinical Pharmacology, vol. 26, no. 2, pp. 180-189, 2012.

[6] A. M. Migahid, Flora of Saudi Arabia, Riyadh University, Riyadh, Saudi Arabia, 2nd edition, 1978.

[7] H. Phillips, History of Cultivated Vegetables, Henry Colburn, London, UK, 1827.

[8] A. Karim and M. K. Bhatty, "Studies on the essential oils of the Pakistani species of the family Umbelliferae. IV. Apium graveolens Linn. (celery, ajmodn) seed oil," Pakistan Journal of Scientific and Industrial Research, vol. 19, pp. 243-246, 1976.

[9] E. Guenther, The Essential Oils, Van Nostrand Reinhold, New York, NY, USA, 1950.

[10] B. Ahmed, T. Alam, M. Varshney, and S. A. Khan, "Hepatoprotective activity of two plants belonging to the Apiaceae and the Euphorbiaceae family," Journal of Ethnopharmacology, vol. 79, no. 3, pp. 313-316, 2002.

[11] A. Singh and S. S. Handa, "Hepatoprotective activity of Apium graveolens and Hygrophila auriculata against paracetamol and thioacetamide intoxication in rats," Journal of Ethnopharmacology, vol. 49, no. 3, pp. 119-126, 1995.

[12] M. Popović, B. Kaurinović, S. Trivić, N. Mimica-Dukić, and M. Bursać, "Effect of celery (Apium graveolens) extracts on some biochemical parameters of oxidative stress in mice treated with carbon tetrachloride," Phytotherapy Research, vol. 20, no. 7, pp. 531-537, 2006.

[13] T. Al-Howiriny, A. Alsheikh, S. Alqasoumi, M. Al-Yahya, K. Eltahir, and S. Rafatullah, "Gastric antiulcer, antisecretory and cytoprotective properties of celery (Apium graveolens) in rats," Pharmaceutical Biology, vol. 48, no. 7, pp. 786-793, 2010.

[14] A. H. Atta and A. Alkofahi, "Anti-nociceptive and anti-inflammatory effects of some Jordanian medicinal plant extracts," Journal of Ethnopharmacology, vol. 60, no. 2, pp. 117-124, 1998.

[15] R. A. Momin and M. G. Nair, "Antioxidant, cyclooxygenase and topoisomerase inhibitory compounds from Apium graveolens Linn. seeds," Phytomedicine, vol. 9, no. 4, pp. 312-318, 2002.

[16] L. M. Perry, Medicinal Plants of East and South East Asia, The MIT Press, London, UK, 1980.

[17] R. Sarin and A. Singh, "Artemisinin content in Artemisia scoparia," Recent Research in Science and Technology, vol. 2, no. 6, pp. 47-50, 2010.

[18] A. H. Gilani and K. H. Janbaz, "Hepatoprotective effects of Artemisia scoparia against carbon tetrachloride: an environmental contaminant," Journal of the Pakistan Medical Association, vol. 44, no. 3, pp. 65-68, 1994.

[19] T. Noguchi, E. K. Lai, S. S. Alexander et al., "Specificity of a phenobarbital-induced cytochrome P-450 for metabolism of carbon tetrachloride to the trichloromethyl radical," Biochemical Pharmacology, vol. 31, no. 5, pp. 615-624, 1982.

[20] A.-U. H. Gilani and K. H. Janbaz, "Protective effect of Artemisia scoparia extract against acetaminophen-induced hepatotoxicity," General Pharmacology, vol. 24, no. 6, pp. 1455-1458, 1993.

[21] C.-X. Liu and G.-Z. Ye, "Choleretic activity of p-hydroxyacetophenone isolated from Artemisia scoparia Waldst. et Kit. in the rat," Phytotherapy Research, vol. 5, no. 4, pp. 182-184, 1991.

[22] M. Habib and I. Waheed, "Evaluation of anti-nociceptive, antiinflammatory and antipyretic activities of Artemisia scoparia hydromethanolic extract," Journal of Ethnopharmacology, vol. 145, no. 1, pp. 18-24, 2013.

[23] H. P. Singh, S. Mittal, S. Kaur, D. R. Batish, and R. K. Kohli, "Chemical composition and antioxidant activity of essential oil from residues of Artemisia scoparia," Food Chemistry, vol. 114, no. 2, pp. 642-645, 2009.

[24] M. Negahban, S. Moharramipour, and M. Yousefelahi, "Efficacy of essential oil from Artemisia scoparia Waldst. \& Kit. against Tribolium castaneum (Herbst) (Coleoptera:Tenebrionidae)," in Proceedings of the 4th International Iran \& Russia Conference, Agricultural and Natural Resources, Shahrekord, Iran, September 2004.

[25] Anonymous, Artemisia scoparia, http://www.naturalmedicinalherbs.net/herbs/a/artemisia-scoparia.php.

[26] S. Lin, Y.-Q. Xiao, Q.-W. Zhang, and N.-N. Zhang, "Studies on chemical constituents in bud of Artemisia scoparia (II)," China Journal of Chinese Materia Medica, vol. 29, no. 2, pp. 152-154, 2004.

[27] S. R. Bammidi, S. S. Volluri, S. C. Chippada, S. Avanigadda, and M. Vangalapati, "A review on pharmacological studies of Bacopa monniera," Journal of Chemical, Biological and Physical Sciences, vol. 1, no. 2, pp. 250-259, 2011.

[28] Anonymous, Brahmi: "Herbs of Grace”, http://www.ayurvedacollege.com/articles/students/Brahmi.

[29] B. R. Menon, M. A. Rathi, L. Thirumoorthi, and V. K. Gopalakrishnan, "Potential effect of Bacopa monniera on nitrobenzene induced liver damage in rats," Indian Journal of Clinical Biochemistry, vol. 25, no. 4, pp. 401-404, 2010.

[30] T. Sumathy, S. Subramanian, S. Govindasamy, K. Balakrishna, and G. Veluchamy, "Protective role of Bacopa monniera on morphine induced hepatotoxicity in rats," Phytotherapy Research, vol. 15, no. 7, pp. 643-645, 2001.

[31] S. Channa, A. Dar, S. Anjum, and M. Yaqoob, "Anti-inflammatory activity of Bacopa monniera in rodents," Journal of Ethnopharmacology, vol. 104, no. 1-2, pp. 286-289, 2006.

[32] J. Joshua Allan, A. Damodaran, N. S. Deshmukh, K. S. Goudar, and A. Amit, "Safety evaluation of a standardized phytochemical composition extracted from Bacopa monniera in SpragueDawley rats," Food and Chemical Toxicology, vol. 45, no. 10, pp. 1928-1937, 2007.

[33] W. Weissner, "Brahmi and Cognition: Nature's Brainpower Enhancer," http://ayurveda-nama.org/pdf/resources/NAMA Brahmi_Weissner.pdf.

[34] D. Sudharani, K. L. Krishna, K. Deval, and A. K. Safia, "Pharmacological profiles of Bacopa monnieri: a review," International Journal of Pharmacy, vol. 1, no. 1, pp. 15-23, 2011.

[35] J. Yadav and M. Panghal, "Balanites aegyptiaca (L.) Del. (Hingot): a review of its traditional uses, phytochemistry and pharmacological properties," International Journal of Green Pharmacy, vol. 4, no. 3, pp. 140-146, 2010.

[36] B. H. Ali, A. K. Bashir, and R. A. Rasheed, "Effect of the traditional medicinal plants Rhazya stricta, Balanitis aegyptiaca and Haplophylum tuberculatum on paracetamol-induced hepatotoxicity in mice," Phytotherapy Research, vol. 15, no. 7, pp. 598603, 2001.

[37] B. Jaiprakash, R. Aland, R. V. Karadi, R. V. Savadi, and V. L. Hukkeri, "Heptoprotective activity of bark of Balanites aegyptiaca Linn.", Journal of Natural Remedies, vol. 3, no. 2, pp. 205207, 2003.

[38] T. M. G. Suky, B. Parthipan, C. Kingston, P. V. R. Mohanand, and T. Soris, "Hepatoprotective and antioxidant effect of Balanites 
aegyptiaca (L.) Del against $\mathrm{CCl}_{4}$ induced hepatotoxicity in rats," International Journal of Pharma Sciences and Research, vol. 2, no. 4, pp. 887-892, 2011.

[39] K. Gaur, R. K. Nema, M. L. Kori, C. S. Sharma, and V. Singh, "Anti-inflammatory and analgesic activity of Balanites aegyptiaca in experimental animal models," International Journal of Green Pharmacy, vol. 2, no. 4, pp. 214-217, 2008.

[40] W. Obidah, M. S. Nadro, G. O. Tiyafo, and A. U. Wurochekke, "Toxicity of crude Balanites aegyptiaca seed oil in rats," Journal of American Science, vol. 5, pp. 13-16, 2009.

[41] D. L. Chothani and H. U. Vaghasiya, "A review on Balanites aegyptiaca Del (desert date): phytochemical constituents, traditional uses, and pharmacological activity," Pharmacognosy Reviews, vol. 5, no. 9, pp. 55-62, 2011.

[42] N. K. Jain and A. K. Singhai, "Protective role of Beta vulgaris L. leaves extract and fractions on ethanol-mediated hepatic toxicity," Acta Poloniae Pharmaceutica-Drug Research, vol. 69, no. 5, pp. 945-950, 2012.

[43] K. R. Kirtikar and B. D. Basu, Text Book of Indian Medicinal Plants, Lalit Mohan Basu, Allahabad, India, 2005.

[44] R. N. Chopra, S. L. Nayar, and I. C. Chopra, Glossary of Indian Medicinal Plants, CSIR, New Delhi, India, 1956.

[45] M. Agarwal, V. K. Srivastava, K. K. Saxena, and A. Kumar, "Hepatoprotective activity of Beta vulgaris against $\mathrm{CCl}_{4}$-induced hepatic injury in rats," Fitoterapia, vol. 77, no. 2, pp. 91-93, 2006.

[46] V. G. Georgiev, J. Weber, E.-M. Kneschke, P. N. Denev, T. Bley, and A. I. Pavlov, "Antioxidant activity and phenolic content of betalain extracts from intact plants and hairy root cultures of the red beetroot Beta vulgaris cv. Detroit Dark Red," Plant Foods for Human Nutrition, vol. 65, no. 2, pp. 105-111, 2010.

[47] R. Chakole, S. Zade, and M. Charde, "Antioxidant and antiinflammatory activity of ethanolic extract of Beta vulgaris Linn. roots," International Journal of Biomedical and Advance Research, vol. 2, no. 4, pp. 124-130, 2011.

[48] K. Rajpoot and R. N. Mishra, "Boerhaavia diffusa roots (Punarnava mool)_review as rasayan (rejuvenator/antiaging)," International Journal of Pharmaceutical and Biomedical Research, vol. 2, no. 4, pp. 1451-1460, 2011.

[49] M. T. Olaleye, A. C. Akinmoladun, A. A. Ogunboye, and A. A. Akindahunsi, "Antioxidant activity and hepatoprotective property of leaf extracts of Boerhaavia diffusa Linn. against acetaminophen-induced liver damage in rats," Food and Chemical Toxicology, vol. 48, no. 8-9, pp. 2200-2205, 2010.

[50] T. Devaki, K. S. Shivashangari, V. Ravikumar, and P. Govindaraju, "Hepatoprotective activity Boerhaavia diffusa on ethanolinduced liver damage in rats," Journal of Natural Remedies, vol. 4, no. 2, pp. 109-115, 2004.

[51] T. N. Bhalla, M. B. Gupta, P. K. Sheth, and K. P. Bhargava, "Antiinflammatory activity of Boerhaavia diffusa," Indian Journal of Physiology and Pharmacology, vol. 6, no. 1, pp. 11-16, 1968.

[52] O. E. Orisakwe, O. J. Afonne, M. A. Chude, E. Obi, and C. E. Dioka, "Sub-chronic toxicity studies of the aqueous extract of Boerhavia diffusa leaves," Journal of Health Science, vol. 49, no. 6, pp. 444-447, 2003.

[53] A. A. Al-Zahim, N. Y. Al-Malki, F. M. Al-Abdulkarim, S. A. Al-Sofayan, H. A. Abunab, and A. A. Abdo, "Use of alternative medicine by Saudi liver disease patients attending a tertiary care center: prevalence and attitudes," Saudi Journal of Gastroenterology, vol. 19, no. 2, pp. 75-80, 2013.

[54] P. Chantre and D. Lairon, "Recent findings of green tea extract AR25 (exolise) and its activity for the treatment of obesity," Phytomedicine, vol. 9, no. 1, pp. 3-8, 2002.
[55] S. Sengottuvelu, S. Duraisami, J. Nandhakumar, R. Duraisami, and M. Vasudevan, "Hepatoprotective activity of Camellia sinensis and its possible mechanism of action," Iranian Journal of Pharmacology and Therapeutics, vol. 7, no. 1, pp. 9-14, 2008.

[56] W. D. Ratnasooriya and T. S. P. Fernando, "Gastric ulcer healing activity of Sri Lankan black tea (Camellia sinensis L.) in rats," Pharmacognosy Magazine, vol. 1, no. 1, pp. 11-20, 2009.

[57] A. K. Nag Chaudhuri, S. Karmakar, D. Roy, S. Pal, M. Pal, and T. Sen, "Anti-inflammatory activity of Indian black tea (Sikkim variety)," Pharmacological Research, vol. 51, no. 2, pp. 169-175, 2005.

[58] P. Sur, T. Chaudhuri, J. R. Vedasiromoni, A. Gomes, and D. K. Ganguly, "Antiinflammatory and antioxidant property of saponins of tea [Camellia sinensis (L.) O. Kuntze] root extract," Phytotherapy Research, vol. 15, no. 2, pp. 174-176, 2001.

[59] A. Gomes, M. Das, J. R. Vedasiromoni, and D. K. Ganguly, "Proconvulsive effect of tea (Camellia sinensis) in mice," Phytotherapy Research, vol. 13, no. 5, pp. 376-379, 1999.

[60] C. Pedrós, G. Cereza, N. García, and J.-R. Laporte, "Liver toxicity of Camellia sinensis dried atanolic extract," Medicina Clinica, vol. 121, no. 15, pp. 598-599, 2003.

[61] H. L. Bonkovsky Md, "Hepatotoxicity associated with supplements containing Chinese green tea (Camellia sinensis)," Annals of Internal Medicine, vol. 144, no. 1, pp. 68-71, 2006.

[62] T. R. Dias, G. Tomás, N. F. Teixeira, M. G. Alves, P. F. Oliveira, and B. M. Silva, "White tea (Camellia sinensis (L.)): antioxidant properties and beneficial health effects," International Journal of Food Science, Nutrition and Dietetics, vol. 2, no. 2, pp. 1-15, 2013.

[63] Anonymous, Indian Medicinal Plants, Orient Longman, Madras, India, 1995.

[64] D. Schuppan, J. I.-D. Jia, B. Brinkhaus, and E. G. Hahn, "Herbal products for liver diseases: a therapeutic challenge for the new millennium," Hepatology, vol. 30, no. 4, pp. 1099-1104, 1999.

[65] Y. B. Solanki and S. M. Jain, "Hepatoprotective effects of Clitoria ternatea and Vigna mungo against acetaminophen and carbon tetrachloride-induced hepatotoxicity in rats," Journal of Pharmacology and Toxicology, vol. 6, no. 1, pp. 30-48, 2011.

[66] K. Nithianantham, M. Shyamala, Y. Chen, L. Y. Latha, S. L. Jothy, and S. Sasidharan, "Hepatoprotective potential of Clitoria ternatea leaf extract against paracetamol induced damage in mice," Molecules, vol. 16, no. 12, pp. 10134-10145, 2011.

[67] K. Narayanasamyd and V. Selvi, "Hepatoprotective effect of a polyherbal formulation (ayush-liv. 04) against ethanol and $\mathrm{CCl}_{4}$ induced liver damage in rats," Ancient Science of Life, vol. 25, no. 1, pp. 28-33, 2005.

[68] B. P. Devi, R. Boominathan, and S. C. Mandal, "Anti-inflammatory, analgesic and antipyretic properties of Clitoria ternatea root," Fitoterapia, vol. 74, no. 4, pp. 345-349, 2003.

[69] M. L. Zingare, P. L. Zingare, A. K. Dubey, and M. A. Ansari, “Clitoria ternatea (Aparajita): a review of the antioxidant, antidiabetic and hepatoprotective potentials," International Journal of Pharmacy and Biological Sciences, vol. 3, no. 1, pp. 203-213, 2012.

[70] N. Kamkaen and J. M. Wilkinson, "The antioxidant activity of Clitoria ternatea flower petal extracts and eye gel," Phytotherapy Research, vol. 23, no. 11, pp. 1624-1625, 2009.

[71] A. D. Taranalli and T. C. Cheeramkuzhy, "Influence of Clitoria ternatea extracts on memory and central cholinergic activity in rats," Pharmaceutical Biology, vol. 38, no. 1, pp. 51-56, 2000.

[72] T. A. Al-Howiriny, M. O. Al-Sohaibani, M. S. Al-Said, M. A. Al-Yahya, K. H. El-Tahir, and S. Rafatullah, "Hepatoprotective properties of Commiphora opobalsamum ("Balessan"), 
a traditional medicinal plant of Saudi Arabia," Drugs under Experimental and Clinical Research, vol. 30, no. 5-6, pp. 213-220, 2004.

[73] W. Dymock, D. Hooper, and C. J. H. Warden, Pharmacographia Indica. A History of the Principal Drugs of Vegetable Origin, Trench, Trubner and Co., London, UK, 1890.

[74] T. A. Al-Howiriny, M. A. Al-Yahya, M. S. Al-Said, K. E. H. El-Tahir, and S. Rafatullah, "Studies on the pharmacological activities of an ethanol extract of balessan (Commiphora opobalsamum)," Pakistan Journal of Biological Sciences, vol. 7, no. 11, pp. 1933-1936, 2004.

[75] T. Al-Howiriny, M. Al-Sohaibani, M. Al-Said, M. Al-Yahya, K. El-Tahir, and S. Rafatullah, "Effect of Commiphora opobalsamum (L.) Engl. (Balessan) on experimental gastric ulcers and secretion in rats," Journal of Ethnopharmacology, vol. 98, no. 3, pp. 287-294, 2005.

[76] Anonymous, Unani Pharmacopoeia, vol. II. India, p. 21 (in Urdu), G.o.I. Unani Pharmacopoeial Committee, New Delhi, India, 2007.

[77] D. Alter, “TURMERIC," http://www.herballegacy.com/Alter History.html.

[78] D. Yadav, S. K. Yadav, R. K. Khar, M. Mujeeb, and M. Akhtar, "Turmeric (Curcuma longa L.): a promising spice for phytochemical and pharmacological activities," International Journal of Green Pharmacy, vol. 7, no. 2, pp. 85-89, 2013.

[79] A. Ramirez-Bosca, A. Soler, M. A. C. Gutierrez, J. L. Alvarez, and E. Q. Almagro, "Antioxidant curcuma extracts decrease the blood lipid peroxide levels of human subjects," Age, vol. 18, no. 4, pp. 167-169, 1995.

[80] R. R. Satoskar, S. J. Shah, and S. G. Shenoy, "Evaluation of antiinflammatory property of curcumin (diferuloyl methane) in patients with postoperative inflammation," International Journal of Clinical Pharmacology Therapy and Toxicology, vol. 24, no. 12, pp. 651-654, 1986.

[81] T. N. Shankar, N. V. Shantha, H. P. Ramesh, I. A. Murthy, and V. S. Murthy, "Toxicity studies on turmeric (Curcuma longa): acute toxicity studies in rats, guinea pigs and monkeys," Indian Journal of Experimental Biology, vol. 18, no. 1, pp. 73-75, 1980.

[82] B. Saad and O. Said, Greco-Arab and Islamic Herbal Medicine: Traditional System, Ethics, Safety, Efficacy, and Regulatory Issues, John Wiley \& Sons, 2011.

[83] Z. Yaniv, D. Schafferman, and Z. Amar, "Tradition, uses and biodiversity of rocket (Eruca sativa, Brassicaceae) in Israel," Economic Botany, vol. 52, no. 4, pp. 394-400, 1998.

[84] S. Alqasoumi, "Carbon tetrachloride-induced hepatotoxicity: protective effect of "Rocket" Eruca sativa L. in rats," The American Journal of Chinese Medicine, vol. 38, no. 1, pp. 75-88, 2010.

[85] J. Hussein, A. Salah, F. Oraby, A. N. El-Deen, and Z. El-Khayat, "Antihepatotoxic effect of Eruca sativa extracts on alcohol induced liver injury in rats," Journal of American Science, vol. 6, no. 11, pp. 381-389, 2010.

[86] E. Lamy, J. Schröder, S. Paulus, P. Brenk, T. Stahl, and V. MerschSundermann, "Antigenotoxic properties of Eruca sativa (rocket plant), erucin and erysolin in human hepatoma (HepG2) cells towards benzo(a)pyrene and their mode of action," Food and Chemical Toxicology, vol. 46, no. 7, pp. 2415-2421, 2008.

[87] M. Sarwar Alam, G. Kaur, Z. Jabbar, K. Javed, and M. Athar, "Eruca sativa seeds possess antioxidant activity and exert a protective effect on mercuric chloride induced renal toxicity," Food and Chemical Toxicology, vol. 45, no. 6, pp. 910-920, 2007.
[88] H. Yehuda, S. Khatib, I. Sussan, R. Musa, J. Vaya, and S. Tamir, "Potential skin antiinflammatory effects of 4-methylthiobutylisothiocyanate (MTBI) isolated from rocket (Eruca sativa) seeds," BioFactors, vol. 35, no. 3, pp. 295-305, 2009.

[89] C. Pérez, J. R. Canal, J. E. Campillo, A. Romero, and M. D. Torres, "Hypotriglyceridaemic activity of Ficus carica leaves in experimental hypertriglyceridaemic rats," Phytotherapy Research, vol. 13, no. 3, pp. 188-191, 1999.

[90] J. R. Canal, M. D. Torres, A. Romero, and C. Pérez, "A chloroform extract obtained from a decoction of Ficus carica leaves improves the cholesterolaemic status of rats with streptozotocininduced diabetes," Acta Physiologica Hungarica, vol. 87, no. 1, pp. 71-76, 2000.

[91] J. F. Morton, Fruits of Warm Climates, Creative Resources Systems, Winterville, NC, USA, 1987.

[92] N. Aghel, H. Kalantari, and S. Rezazadeh, "Hepatoprotective effect of Ficus carica leaf extract on mice intoxicated with carbon tetrachloride," Iranian Journal of Pharmaceutical Research, vol. 10, no. 1, pp. 63-68, 2011.

[93] A. N. B. Singab, N. A. Ayoub, E. N. Ali, and N. M. Mostafa, "Antioxidant and hepatoprotective activities of Egyptian moraceous plants against carbon tetrachloride-induced oxidative stress and liver damage in rats," Pharmaceutical Biology, vol. 48, no. 11, pp. 1255-1264, 2010.

[94] M. Mujeeb, S. A. Khan, V. Aeri, and B. Ali, "Hepatoprotective activity of the ethanolic extract of Ficus carica Linn. leaves in carbon tetrachloride-induced hepatotoxicity in rats," Iranian Journal of Pharmaceutical Research, vol. 10, no. 2, pp. 301-306, 2011.

[95] N. Gond and S. Khadabadi, "Hepatoprotective activity of Ficus carica leaf extract on rifampicin-induced hepatic damage in rats," Indian Journal of Pharmaceutical Sciences, vol. 70, no. 3, pp. 364-366, 2008.

[96] B. Ali, M. Mujeeb, V. Aeri, S. R. Mir, M. Faiyazuddin, and F. Shakeel, "Anti-inflammatory and antioxidant activity of Ficus carica Linn. leaves," Natural Product Research, vol. 26, no. 5, pp. 460-465, 2012.

[97] B. Joseph and S. Justin Raj, "Pharmacognostic and phytochemical properties of Ficus carica Linn.- - an overview," International Journal of PharmTech Research, vol. 3, no. 1, pp. 8-12, 2011.

[98] D. Bonamonte, C. Foti, N. Lionetti, L. Rigano, and G. Angelini, "Photoallergic contact dermatitis to 8-methoxypsoralen in Ficus carica," Contact Dermatitis, vol. 62, no. 6, pp. 343-348, 2010.

[99] H. M. Al-Youssef, M. Amina, and A. M. El-shafae, "Biological evaluation of constituents from Grewia mollis," Journal of Chemical and Pharmaceutical Research, vol. 4, no. 1, pp. 508518, 2012.

[100] D. Louppe, A. A. Oteng-Amoako, and M. Brink, Plant Resources of Tropical Africa 7(1), PROVA Foundation, Wageningen, The Netherlands; Backhuys Publishers, Lenden, The Netherlands; CTA, Wageningen, The Netherlands, 2008.

[101] J. M. Dalziel, The Useful Plants of West Africa, Crown Agents, London, UK, 1937.

[102] O. Asuku, S. E. Atawodi, and E. Onyike, "Antioxidant, hepatoprotective, and ameliorative effects of methanolic extract of leaves of Grewia mollis Juss. on carbon tetrachloride-treated albino rats," Journal of Medicinal Food, vol. 15, no. 1, pp. 83-88, 2012.

[103] W. Obidah, J. L. Godwin, J. Z. Fate, and M. A. Madusolumuo, "Toxic effects of Grewia mollis stem bark in experimental rats," Journal of American Science, vol. 6, no. 12, pp. 1544-1548, 2010. 
[104] O. Safa, M. A. Soltanipoor, S. Rastegar, M. Kazemi, K. Nourbakhsh Dehkordi, and A. Ghannadi, "An ethnobotanical survey on Hormozgan province, Iran," Avicenna Journal of Phytomedicine, vol. 3, no. 1, pp. 64-81, 2012.

[105] M. S. Al-Said, R. A. Mothana, M. O. Al-Sohaibani, and S. Rafatullah, "Ameliorative effect of Grewia tenax (Forssk) fiori fruit extract on $\mathrm{CCl}_{4}$-induced oxidative stress and hepatotoxicity in rats," Journal of Food Science, vol. 76, no. 9, pp. T200-T206, 2011.

[106] N. H. Saleem, V. A. Ferro, A. M. Simpson, J. Igoli, A. I. Gray, and R. M. Drummond, "The inhibitory effect of Haloxylon salicornicum on contraction of the mouse uterus," Evidence-Based Complementary and Alternative Medicine, vol. 2013, Article ID 714075, 10 pages, 2013.

[107] M. S. Shafi, M. Y. Ashraf, and G. Sarwar, "Wild medicinal plants of Cholistan area of Pakistan," Pakistan Journal of Biological Sciences, vol. 4, no. 1, pp. 112-116, 2001.

[108] H. M. Wariss, S. Ahmad, S. Anjum, and K. Alam, "Ethnobotanical studies of dicotyledonous plants of Lal Suhanra National Park, Bahawalpur, Pakistan," International Journal of Science and Research, vol. 3, no. 6, pp. 2452-2460, 2012.

[109] M. Ahmad and S. Eram, "Hepatoprotective studies on Haloxylon salicornicum: a plant from Cholistan desert," Pakistan Journal of Pharmaceutical Sciences, vol. 24, no. 3, pp. 377-382, 2011.

[110] S. I. Alqasoumi, G. A. E. H. Soliman, A. S. Awaad, and A. E. R. M. Donia, "Anti-inflammatory activity, safety and protective effects of Leptadenia pyrotechnica, Haloxylon salicornicum and Ochradenus baccatus in ulcerative colitis," Phytopharmacology, vol. 2, no. 1, pp. 58-71, 2012.

[111] S. Ferheen, E. Ahmed, N. Afza, and A. Malik, "Phytochemical studies on Haloxylon salicornicum," Journal of the Chemical Society of Pakistan, vol. 27, no. 2, pp. 219-222, 2005.

[112] I. Roman, M. Cristescu, and C. Puica, "Effects of Hypericum perforatum and Hypericum maculatum extracts administration on some morphological and biochemical parameters in rat liver intoxicated with alcohol," Studia Universitatis "Vasile Goldiş", Seria Ştiinţele Vieţii, vol. 21, no. 2, pp. 361-370, 2011.

[113] Y. Ozturk, S. Aydin, K. H. C. Baser, N. Kirimer, and N. KurtarOzturk, "Hepatoprotective activity of Hypericum perforatum L. alcoholic extract in rodents," Phytotherapy Research, vol. 6, no. 1, pp. 44-46, 1992.

[114] C. Celen, S. Ozkan, and F. Ayhan, "The phenolic compounds from Hypericum perforatum and their antimicrobial activities," Hacettepe Journal of Biology and Chemistry, vol. 36, no. 4, pp. 339-345, 2008.

[115] J. M. Greeson, B. Sanford, and D. A. Monti, "St. John's wort (Hypericum perforatum): a review of the current pharmacological, toxicological, and clinical literature," Psychopharmacology, vol. 153, no. 4, pp. 402-414, 2001.

[116] S. I. Alqasoumi, Isolation and Chemical Structure Elucidation of Hepatoprotective Constituents from Plants Used in Traditional Medicine in Saudi Arabia, College of Pharmacy, King Saud University, 2007.

[117] S. I. Alqasoumi and M. S. Abdel-Kader, "Terpenoids from Juniperus procera with hepatoprotective activity," Pakistan Journal of Pharmaceutical Sciences, vol. 25, no. 2, pp. 315-322, 2012.

[118] D. Manohar, G. L. Viswanatha, S. Nagesh, V. Jain, and H. N. Shivaprasad, "Ethnopharmacology of Lepidium sativum Linn. (Brassicaceae): a review," International Journal of Phytothearpy Research, vol. 2, no. 1, pp. 1-7, 2012.

[119] S. K. Biswas, A. Chowdhury, J. Das, A. Roy, and S. M. Z. Hosen, "Pharmacological potentials of Moringa oleifera Lam.: a review,"
International Journal of Pharmaceutical Science Research, vol. 3, no. 2, pp. 305-310, 2012.

[120] S. G. Mahajan and A. A. Mehta, "Effect of Moringa oleifera Lam. seed extract on ovalbumin-induced airway inflammation in guinea pigs," Inhalation Toxicology, vol. 20, no. 10, pp. 897909, 2008.

[121] U. K. Mazumder, M. Gupta, S. Chakrabarti, and D. Pal, "Evaluation of hematological and hepatorenal functions of methanolic extract of Moringa oleifera Lam. root treated mice," Indian Journal of Experimental Biology, vol. 37, no. 6, pp. 612-614, 1999.

[122] F. Anwar, S. Latif, M. Ashraf, and A. H. Gilani, "Moringa oleifera: a food plant with multiple medicinal uses," Phytotherapy Research, vol. 21, no. 1, pp. 17-25, 2007.

[123] M. Tariq, "Nigella sativa seeds: folklore treatment in modern day medicine," Saudi Journal of Gastroenterology, vol. 14, no. 3, pp. 105-106, 2008.

[124] M. L. A. Khan, “Tibb-Al-Nabvi: Nigella sativa," Islamic Voice, vol. 13-18, no. 152, pp. 1-2, 1999.

[125] A. Ahmad, A. Husain, M. Mujeeb et al., "A review on therapeutic potential of Nigella sativa: a miracle herb," Asian Pacific Journal of Tropical Biomedicine, vol. 3, no. 5, pp. 337-352, 2013.

[126] A. Sharma, M. S. Sharma, A. Mishra, S. Sharma, B. Kumar, and A. Bhandari, "A review on the plants used in liver disease," International Journal of Research in Pharmacy and Chemistry, vol. 1, no. 2, pp. 224-236, 2011.

[127] S. Y. Diwan, "Effect of Peganum harmala methanol extract on liver and kidney of mice administered MTX drug," Journal of Al-Nahrain University, vol. 16, no. 4, pp. 161-166, 2013.

[128] A. B. Gulshan, A. A. Dasti, S. Hussain, M. I. Atta, and M. Aminud-Din, "Indigenous uses of medicinal plants in rural areas of Dera Ghazi Khan, Punjab, Pakistan," Journal of Agricultural and Biological Science, vol. 7, no. 9, pp. 750-762, 2012.

[129] C. Ratsch, The Encyclopedia of Psychoactive Plants: Ethnopharmacology and Its Application, Park Street Press, Rochester, Vt, USA, 1998.

[130] J. Asgarpanah and F. Ramezanloo, "Chemistry, pharmacology and medicinal properties of Peganum harmala L.", African Journal of Pharmacy and Pharmacology, vol. 6, no. 22, pp. 15731580, 2012.

[131] K. Hamden, H. Masmoudi, F. Ellouz, A. Elfeki, and S. Carreau, "Protective effects of Peganum harmala extracts on thioureainduced diseases in adult male rat," Journal of Environmental Biology, vol. 29, no. 1, pp. 73-77, 2008.

[132] V. H. Bhaskar and N. Balakrishnan, "Analgesic, anti-inflammatory and antipyretic activities of Pergularia daemia and Carissa carandas," Daru, vol. 17, no. 3, pp. 168-174, 2009.

[133] V. H. Bhaskar and N. Balakrishnan, "Protective effects of Pergularia daemia roots against paracetamol and carbon tetrachloride-induced hepatotoxicity in rats," Pharmaceutical Biology, vol. 48, no. 11, pp. 1265-1272, 2010.

[134] S. V. Sureshkumar and S. H. Mishra, "Hepatoprotective effect of extracts from Pergularia daemia Forsk," Journal of Ethnopharmacology, vol. 107, no. 2, pp. 164-168, 2006.

[135] S. V. S. Kumar and S. H. Mishra, "Hepatoprotective effect of Pergularia daemia (Forsk.) ethanol extract and its fraction," Indian Journal of Experimental Biology, vol. 46, no. 6, pp. 447-452, 2008.

[136] D. Hoffmann, Medical Herbalism: The Science and Practice of Herbal Medicine, Healing Arts Press, 2010.

[137] Y. A. Leung, Encyclopedia of Common Natural Ingredients Used in Food, Drug and Cosmetics, John Wiley \& Sons, New York, NY, USA, 1988. 
[138] T. A. Al-Howiriny, M. O. Al-Sohaibani, K. H. El-Tahir, and S. Rafatullah, "Preliminary evaluation of the anti-inflammatory and anti-hepatotoxic activities of 'Parsley' Petroselinum crispum in rats," Journal of Natural Remedies, vol. 3, no. 1, pp. 54-62, 2003.

[139] H. Eckey-Kaltenbach, D. Ernst, W. Heller, and H. Sandermann Jnr, "Biochemical plant responses to ozone. IV.Cross-induction of defensive pathways in parsley (Petroselinum crispum L.) plants," Plant Physiology, vol. 104, no. 1, pp. 67-74, 1994.

[140] D. S. A. Chaves, F. S. Frattani, M. Assafim, A. P. de Almeida, R. B. Zingali, and S. S. Costa, "Phenolic chemical composition of Petroselinum crispum extract and its effect on haemostasis," Natural Product Communications, vol. 6, no. 7, pp. 961-964, 2011.

[141] J. O. B. Calixto, A. R. S. Santos, and R. A. Yunes, "A review of the plants of the genus Phyllanthus: their chemistry, pharmacology, and therapeutic potential," Medicinal Research Reviews, vol. 18, no. 4, pp. 225-258, 1998.

[142] V. V. Asha, M. S. Sheeba, V. Suresh, and P. J. Wills, "Hepatoprotection of Phyllanthus maderaspatensis against experimentally induced liver injury in rats," Fitoterapia, vol. 78, no. 2, pp. 134141, 2007.

[143] M. Karthikeyan, J. A. Mathews, and A. Annamalai, "Antibacterial activity of Phyllanthus maderaspatensis leaves extract," Pharma Science Monitor, vol. 3, no. 3, pp. 1-10, 2012.

[144] N. Ravichandran, R. Vajrai, C. D. Raj, and P. Brindha, "Phytochemical analysis and in vitro cytotoxic effect of Phyllanthus madraspatensis L.," International Journal of Pharmacy and Pharmaceutical Sciences, vol. 4, no. 2, pp. 111-114, 2012.

[145] W. B. Jonas, Mosby's Dictionary of Complementary and Alternative Medicine, Mosby, 2005.

[146] M. M. Özcan and J. C. Chalchat, "Chemical composition and antifungal effect of anise (Pimpinella anisum L.) fruit oil at ripening stage," Annals of Microbiology, vol. 56, no. 4, pp. 353358, 2006.

[147] A. Shojaii and M. A. Fard, "Review of pharmacological properties and chemical constituents of Pimpinella anisum," ISRN Pharmaceutics, vol. 2012, Article ID 510795, 8 pages, 2012.

[148] M. Ahmad, A. Itoo, I. Baba, S. M. Jain, and R. C. Saxena, "Hepatoprotective activity of Portulaca oleracea Linn. on experimental animal model," International Journal of Pharmacy and Pharmaceutical Sciences, vol. 5, no. 3, pp. 267-269, 2013.

[149] M. Anusha, M. Venkateswarlu, V. Prabhakaran, S. S. Taj, B. P. Kumari, and D. Ranganayakulu, "Hepatoprotective activity of aqueous extract of Portulaca oleracea in combination with lycopene in rats," Indian Journal of Pharmacology, vol. 43, no. 5, pp. 563-567, 2011.

[150] A. N. Rasheed, F. U. Afifi, M. Shaedah, and M. O. Taha, "Investigation of the active constituents of Portulaca oleraceae L. (Portulacaceae) growing in Jordan," Pakistan Journal of Pharmaceutical Sciences, vol. 17, no. 1, pp. 37-45, 2004.

[151] C. V. Chowdhary, A. Meruva, K. Naresh, and R. K. A. Elumalai, "A review on phytochemical and pharmacological profile of Portulaca oleracea Linn. (Purslane)," International Journal of Research in Ayurveda and Pharmacy, vol. 4, no. 1, pp. 34-37, 2013.

[152] N. Deshwal, A. K. Sharma, and P. Sharma, "Review on hepatoprotective plants," International Journal of Pharmaceutical Sciences Review and Research, vol. 7, no. 1, pp. 15-26, 2011.

[153] A. A. Al Gonemi, Encyclopaedia of the United Arab Emirates Plants Used in Folk Medicine, United Arab Emirates University Press, Al-Ain, UAE, 1992, (Arabic).
[154] S. K. Marwat, F. Rehman, K. Usman, S. S. Shah, N. Anwar, and I. Ullah, "A review of phytochemistry, bioactivities and ethno medicinal uses of Rhazya stricta Decsne (Apocynaceae)," African Journal of Microbiology Research, vol. 6, no. 8, pp. 16291641, 2012.

[155] B. H. Ali, A. A. Al-Qarawi, A. K. Bashir, and M. O. Tanira, "Phytochemistry, pharmacology and toxicity of Rhazya stricta decne: a review," Phytotherapy Research, vol. 14, no. 4, pp. 229234, 2000.

[156] M. A. Ghani, Khazeenat-Al-Advia, vol. 111, Matbaa Naval Kishore, Lucknow, India, 1921.

[157] A. K. Raza, Tazkiratul-Hind, Yadgaar Razaee, Shamsul-Islam Press, Hyderabad, India, 1933.

[158] F. H. Albert, Economic Botany, McGraw-Hill, New York, NY, USA, 1952.

[159] A. M. Ageel, J. S. Mossa, M. A. Al-Yahya, M. S. Al-Said, and M. Tariq, "Experimental studies on antirheumatic crude drugs used in Saudi traditional medicine," Drugs under Experimental and Clinical Research, vol. 15, no. 8, pp. 369-372, 1989.

[160] Anonymous, “Tropical plant database," http://www.rain-tree .com/sarsaparilla.htm\#.VAsc-Pmlagw.

[161] B. Dash, Herbal Cure: Jaundice and Liver Disorders, B. Jain Publishers, 2004.

[162] S. Sultana, S. Perwaiz, M. Iqbal, and M. Athar, "Crude extracts of hepatoprotective plants, Solanum nigrum and Cichoriunz intybus inhibit free radical-mediated DNA damage," Journal of Ethnopharmacology, vol. 45, no. 3, pp. 189-192, 1995.

[163] N. N. Wannang, J. A. Anuka, H. O. Kwanashie, S. S. Gyang, and A. Auta, "Anti-seizure activity of the aqueous leaf extract of Solanum nigrum Linn. (solanaceae) in experimental animals," African Health Sciences, vol. 8, no. 2, pp. 74-79, 2008.

[164] R. Jain, A. Sharma, S. Gupta, I. P. Sarethy, and R. Gabrani, "Solanum nigrum: current perspectives on therapeutic properties," Alternative Medicine Review, vol. 16, no. 1, pp. 78-85, 2011.

[165] H.-M. Lin, H.-C. Tseng, C.-J. Wang, J.-J. Lin, C.-W. Lo, and F.-P. Chou, "Hepatoprotective effects of Solanum nigrum Linn. extract against $\mathrm{CCl}_{4}$-iduced oxidative damage in rats," ChemicoBiological Interactions, vol. 171, no. 3, pp. 283-293, 2008.

[166] S. Singh, S. K. Sharma, and R. Mann, "Pharmacognostical standardization of stem of Suaeda maritima (L.) Dumort," International Journal of Pharmacy and Pharmaceutical Sciences, vol. 4, no. 3, pp. 304-306, 2012.

[167] S. Ravikumar, M. Gnanadesigan, S. Jacob Inbaneson, and A. Kalaiarasi, "Hepatoprotective and antioxidant properties of Suaeda maritima (L.) Dumort ethanolic extract on concanavalin-A induced hepatotoxicity in rats," Indian Journal of Experimental Biology, vol. 49, no. 6, pp. 455-460, 2011.

[168] S. Singh, R. Mann, and S. K. Sharma, "Pharmacognostical standardization of root of Suaeda maritima (L.) dumort," Der Pharmacia Lettre, vol. 5, no. 1, pp. 116-120, 2013.

[169] I. Sina, Al Qanoon Fil Tib, vol. 522, Mataba Munshi Naval Kishore, Lucknow, India, 2007.

[170] R. O. Bakr, M. A. E.-A. El Raey, and R. S. Ashour, "Phenolic content, radical scavenging activity and cytotoxicity of Tamarix nilotica (Ehrenb.) bunge growing in Egypt," Journal of Pharmacognosy and Phytotherapy, vol. 5, no. 3, pp. 47-52, 2013.

[171] S. Abouzid and A. Sleem, "Hepatoprotective and antioxidant activities of Tamarix nilotica flowers," Pharmaceutical Biology, vol. 49, no. 4, pp. 392-395, 2011.

[172] R. M. Sree and M. Srinivasan, "Hepatoprotective effect of Tephrosia purprea in experimental animals," Indian Journal of Pharmacology, vol. 25, no. 1, pp. 34-36, 1993. 
[173] A. Kumar, M. Dutta, T. K. Bhatt, and D. S. Dalal, "Use of herbal liver tonic yakrifit in equine practice," Indian Veterinary Journal, vol. 74, no. 5, pp. 424-425, 1997.

[174] P. A. Jitendra and T. A. Pravin, "Prospective use of Tephrosia purpurea in remedial treatment of PCOS: study in Wistar rat," ISCA Journal of Biological Sciences, vol. 1, no. 3, pp. 1-6, 2012.

[175] A. Khatri, A. Garg, and S. S. Agrawal, "Evaluation of hepatoprotective activity of aerial parts of Tephrosia purpurea L. and stem bark of Tecomella undulata," Journal of Ethnopharmacology, vol. 122, no. 1, pp. 1-5, 2009.

[176] K. H. Janbaz, M. I. Qadir, A. Jan, and A. H. Gilani, "Antidiarrheal activity of methanolic extract of Tephrosia purpurea," Acta Poloniae Pharmaceutica-Drug Research, vol. 70, no. 2, pp. 345-347, 2013.

[177] M. Tariq, A. M. Ageel, M. A. Al-Yahya, J. S. Mossa, and M. S. Al-Said, "Anti-inflammatory activity of Teucrium polium," International Journal of Tissue Reactions, vol. 11, no. 4, pp. 185-188, 1989.

[178] T. K. Panovska, S. Kulevanova, I. Gjorgoski, M. Bogdanova, and G. Petrushevska, "Hepatoprotective effect of the ethyl acetate extract of Teucrium polium L. against carbontetrachlorideinduced hepatic injury in rats," Acta Pharmaceutica, vol. 57, no. 2, pp. 241-248, 2007.

[179] M. B. Gholivand, M. Piryaei, M. M. Abolghasemi, and S. M. Maassoumi, "Rapid analysis of volatile components from Teucrium polium L. by nanoporous silica-polyaniline solid phase microextraction fibre," Phytochemical Analysis, vol. 24, no. 1, pp. 69-74, 2013.

[180] S. Bahramikia and R. Yazdanparast, "Phytochemistry and medicinal properties of Teucrium polium L. (Lamiaceae)," Phytotherapy Research, vol. 26, no. 11, pp. 1581-1593, 2012.

[181] C. Moustapha, M. W. Taher Hasen, and M. Sadaka, "Chemical constituents of Teucrium polium L. var. mollissimum HandMazz," Jordan Journal of Chemistry, vol. 6, no. 3, pp. 339-345, 1975.

[182] M. K. Shivhare, P. K. Singour, P. K. Chaurasiya, and R. S. Pawar, "Trianthema portulacastrum Linn. (bishkhapra)," Pharmacognosy Reviews, vol. 6, no. 12, pp. 132-140, 2012.

[183] S. G. Banu, G. Kumar, and A. G. Murugesan, "Ethanolic leaves extract of Trianthema portulacastrum L. ameliorates aflatoxin B1 induced hepatic damage in rats," Indian Journal of Clinical Biochemistry, vol. 24, no. 3, pp. 250-256, 2009.

[184] A. Amin, M. Lotfy, M. Shafiullah, and E. Adeghate, "The protective effect of Tribulus terrestris in diabetes," Annals of the New York Academy of Sciences, vol. 1084, pp. 391-401, 2006.

[185] I. Kostova and D. Dinchev, "Saponins in Tribulus terrestrischemistry and bioactivity," Phytochemistry Reviews, vol. 4, no. 2-3, pp. 111-137, 2005.

[186] E. A. A. Aboagarib, R. Yang, X. Hua, and A. Siddeeg, "Chemical compositions, nutritional properties and volatile compounds of guddaim (Grewia tenax. Forssk) Fiori Fruits," Journal of Food and Nutrition Research, vol. 2, no. 4, pp. 187-192, 2014.

[187] M. A. Al-Shanawani, Plant Used in Saudi Folk Medicine, King Abdul-Aziz City for Science and Technology, Riyadh, Saudi Arabia, 1996.

[188] A. M. El-Shazly, G. Dora, and M. Wink, "Alkaloids of Haloxylon salicornicum (Moq.) Bunge ex Boiss. (Chenopodiaceae)," Pharmazie, vol. 60, no. 12, pp. 949-952, 2005.

[189] C. I. Istikoglou, V. Mavreas, and G. Geroulanos, "History and therapeutic properties of Hypericum perforatum from antiquity until today," Psychiatrikē, vol. 21, no. 4, pp. 332-338, 2010.
[190] J. Aliasl and F. Khoshzaban, "Traditional herbal remedies for burn wound healing in canon of Avicenna," Jundishapur Journal of Natural Pharmaceutical Products, vol. 8, no. 4, pp. 192-196, 2013.

[191] K. Šavikin, S. Dobrić, V. Tadić, and G. Zdunić, "Antiinflammatory activity of ethanol extracts of Hypericum perforatum L., $H$. barbatum Jacq., H. hirsutum L., H. richeri Vill. and H. androsaemum L. in rats," Phytotherapy Research, vol. 21, no. 2, pp. 176180, 2007.

[192] V. Kumar, P. N. Singh, and S. K. Bhattacharya, "Anti-inflammatory and analgesic activity of Indian Hypericum perforatum L."' Indian Journal of Experimental Biology, vol. 39, no. 4, pp. 339-343, 2001.

[193] F. A. Andersen, "Final report on the safety assessment of Hypericum perforatum extract and Hypericum perforatum oil," International Journal of Toxicology, vol. 20, supplement 2, pp. 31-39, 2001.

[194] M. Burits, K. Asres, and F. Bucar, "The antioxidant activity of the essential oils of Artemisia afra, Artemisia abyssinica and Juniperus procera," Phytotherapy Research, vol. 15, no. 2, pp. $103-$ 108, 2001.

[195] H. Tunón, C. Olavsdotter, and L. Bohlin, "Evaluation of antiinflammatory activity of some Swedish medicinal plants. Inhibition of prostaglandin biosynthesis and PAF-induced exocytosis," Journal of Ethnopharmacology, vol. 48, no. 2, pp. 61-76, 1995.

[196] A. I. Abuelgasim, H. S. Nuha, and A. H. Mohammed, "Hepatoprotective effect of Lepidium sativum against carbon tetrachloride induced damage in rats," Research Journal of Animal \& Veterinary Sciences, vol. 3, pp. 20-23, 2008.

[197] Y. C. Yadav, D. N. Srivastav, A. K. Seth, V. Saini, R. Balaraman, and T. K. Ghelani, "In vivo antioxidant potential of Lepidium sativum L. seeds in albino rats using cisplatin induced nephrotoxicity," International Journal of Phytomedicine, vol. 2, no. 3, pp. 292-298, 2010.

[198] M. Zia-Ul-Haq, S. Ahmad, L. Calani et al., "Compositional study and antioxidant potential of Ipomoea hederacea Jacq. and Lepidium sativum L. seeds," Molecules, vol. 17, no. 9, pp. 1030610321, 2012.

[199] J. Agarwal and D. L. Verma, "Antioxidant activity-guided fractionation of aqueous extracts from Lepidium sativum and identification of active flavonol glycosides," Academia Arena, vol. 3, no. 12, pp. 14-18, 2011.

[200] N. D. Raval, B. Ravishankar, and B. K. Ashok, "Anti-inflammatory effect of Chandrashura (Lepidium sativum Linn.) an experimental study," Ayu, vol. 34, no. 3, pp. 302-304, 2013.

[201] S. E. I. Adam, "Effects of various levels of dietary Lepidium sativum L. seeds in rats," The American Journal of Chinese Medicine, vol. 27, no. 3-4, pp. 397-405, 1999.

[202] B. S. Ajilore, T. G. Atere, W. A. Oluogun, and V. A. Aderemi, "Protective effects of Moringa oleifera Lam. on cadmiuminduced liver and kidney damage in male Wistar rats," International Journal of Phytotherapy Research, vol. 2, no. 3, pp. 42-50, 2012.

[203] L. Pari and N. A. Kumar, "Hepatoprotective activity of Moringa oleifera on antitubercular drug-induced liver damage in rats," Journal of Medicinal Food, vol. 5, no. 3, pp. 171-177, 2002.

[204] S. Sreelatha and P. R. Padma, "Antioxidant activity and total phenolic content of Moringa oleifera leaves in two stages of maturity," Plant Foods for Human Nutrition, vol. 64, no. 4, pp. 303-311, 2009. 
[205] M. Minaiyan, G. Asghari, D. Taheri, M. Saeidi, and S. NasrEsfahani, "Anti-inflammatory effect of Moringa oleifera Lam. seeds on acetic acid-induced acute colitis in rats," Avicenna Journal of Phytomedicine, vol. 4, no. 2, pp. 127-136, 2014.

[206] B. S. Rathi, S. L. Bodhankar, and A. M. Baheti, "Evaluation of aqueous leaves extract of Moringa oleifera Linn. for wound healing in albino rats," Indian Journal of Experimental Biology, vol. 44, no. 11, pp. 898-901, 2006.

[207] F. Yildiz, S. Coban, A. Terzi et al., "Nigella sativa relieves the deleterious effects of ischemia reperfusion injury on liver," World Journal of Gastroenterology, vol. 14, no. 33, pp. 5204-5209, 2008.

[208] E. A. Al-Suhaimi, "Hepatoprotective and immunological functions of Nigella sativa seed oil against hypervitaminosis A in adult male rats," International Journal for Vitamin and Nutrition Research, vol. 82, no. 4, pp. 288-297, 2012.

[209] A. M. S. Gani and S. A. John, "Evalution of hepatoprotective effect of Nigella sativa L.," International Journal of Pharmacy and Pharmaceutical Sciences, vol. 5, no. 4, pp. 428-430, 2013.

[210] M. S. Al-Ghamdi, "Protective effect of Nigella sativa seeds against carbon tetrachloride-induced liver damage," American Journal of Chinese Medicine, vol. 31, no. 5, pp. 721-728, 2003.

[211] J. Danladi, A. Abdulsalam, J. A. Timbuak, S. A. Ahmed, M. Aa, and A. U. Dahiru, "Hepatoprotective effect of black seed (Nigella sativa) oil on carbon tetrachloride $\left(\mathrm{CCl}_{4}\right)$ induced liver toxicity in adult wistar rats," IOSR-Journal of Dental and Medical Science, vol. 4, no. 3, pp. 56-62, 2013.

[212] M. Alemi, F. Sabouni, F. Sanjarian, K. Haghbeen, and S. Ansari, "Anti-inflammatory effect of seeds and Callus of Nigella sativa L. extracts on mix glial cells with regard to their thymoquinone content," AAPS PharmSciTech, vol. 14, no. 1, pp. 160-167, 2013.

[213] N. Chehl, G. Chipitsyna, Q. Gong, C. J. Yeo, and H. A. Arafat, "Anti-inflammatory effects of the Nigella sativa seed extract, thymoquinone, in pancreatic cancer cells," $H P B$, vol. 11, no. 5, pp. 373-381, 2009.

[214] M. S. Al-Ghamdi, "The anti-inflammatory, analgesic and antipyretic activity of Nigella sativa," Journal of Ethnopharmacology, vol. 76, no. 1, pp. 45-48, 2001.

[215] M.-H. Boskabady, R. Keyhanmanesh, S. Khameneh, Y. Doostdar, and M.-R. Khakzad, "Potential immunomodulation effect of the extract of Nigella sativa on ovalbumin sensitized guinea pigs," Journal of Zhejiang University: Science B, vol. 12, no. 3, pp. 201-209, 2011.

[216] X.-F. Leong, M. R. Mustafa, and K. Jaarin, "Nigella sativa and its protective role in oxidative stress and hypertension," EvidenceBased Complementary and Alternative Medicine, vol. 2013, Article ID 120732, 9 pages, 2013.

[217] A. Zaoui, Y. Cherrah, N. Mahassini, K. Alaoui, H. Amarouch, and M. Hassar, "Acute and chronic toxicity of Nigella sativa fixed oil," Phytomedicine, vol. 9, no. 1, pp. 69-74, 2002.

[218] A. J. Tanweer, N. Chand, S. Khan et al., "Association of Peganum harmala L. supplementation with liver function test of broiler chicks," Pakistan Journal of Science, vol. 64, no. 1, pp. 75-79, 2012.

[219] H. Ahmed, H. Abu El Zahab, and G. Alswiai, "Purification of antioxidant protein isolated from Peganum harmala and its protective effect against $\mathrm{CCl}_{4}$ toxicity in rats," Turkish Journal of Biology, vol. 37, no. 1, pp. 39-48, 2013.

[220] P. Bremner, D. Rivera, M. A. Calzado et al., "Assessing medicinal plants from South-Eastern Spain for potential antiinflammatory effects targeting nuclear factor-Kappa B and other pro-inflammatory mediators," Journal of Ethnopharmacology, vol. 124, no. 2, pp. 295-305, 2009.
[221] Z. Muhi-Eldeen, K. J. Al-Shamma, T. M. Al-Hussainy, E. N. AlKaissi, A. M. Al-Daraji, and H. Ibrahim, "Acute toxicological studies on the extract of Iraqi Peganum harmala in rats," European Journal of Scientific Research, vol. 22, no. 4, pp. 494$500,2008$.

[222] F. Lamchouri, A. Settaf, Y. Cherrah et al., "Experimental toxicity of Peganum harmala seeds," Annales Pharmaceutiques Francaises, vol. 60, no. 2, pp. 123-129, 2002.

[223] T. Herraiz, D. González, C. Ancín-Azpilicueta, V. J. Arán, and H. Guillén, " $\beta$-carboline alkaloids in Peganum harmala and inhibition of human monoamine oxidase (MAO)," Food and Chemical Toxicology, vol. 48, no. 3, pp. 839-845, 2010.

[224] K. M. R. Sravani, C. K. A. Kumar, S. M. Lakshmi, and G. S. Rani, "Psychopharmacological profiles of Pergularia daemia (forsk.) Chiov," Asian Journal of Pharmaceutical and Clinical Research, vol. 5, no. 2, pp. 112-114, 2012.

[225] H. Zhang, F. Chen, X. I. Wang, and H.-Y. Yao, "Evaluation of antioxidant activity of parsley (Petroselinum crispum) essential oil and identification of its antioxidant constituents," Food Research International, vol. 39, no. 8, pp. 833-839, 2006.

[226] P. Y. Y. Wong and D. D. Kitts, "Studies on the dual antioxidant and antibacterial properties of parsley (Petroselinum crispum) and cilantro (Coriandrum sativum) extracts," Food Chemistry, vol. 97, no. 3, pp. 505-515, 2006.

[227] D. Bown, Encyclopedia of Herbs and Their Uses, Dorling Kindersley, London, UK, 1995.

[228] A. Munshi, R. Mehrotra, and S. K. Panda, "Evaluation of Phyllanthus amarus and Phyllanthus maderaspatensis as agents for postexposure prophylaxis in neonatal duck hepatitis B virus infection," Journal of Medical Virology, vol. 40, no. 1, pp. 53-58, 1993.

[229] A. Kumaran and R. J. Karunakaran, "In vitro antioxidant activities of methanol extracts of five Phyllanthus species from India," LWT: Food Science and Technology, vol. 40, no. 2, pp. 344-352, 2007.

[230] Y. K. Rao, S.-H. Fang, and Y.-M. Tzeng, "Anti-inflammatory activities of constituents isolated from Phyllanthus polyphyllus," Journal of Ethnopharmacology, vol. 103, no. 2, pp. 181-186, 2006.

[231] R. Kuttan and K. B. Harikumar, Phyllanthus Species: Scientific Evaluation and Medicinal Applications, CRC Press, New York, NY, USA, 2011.

[232] N. Cengiz, H. Ozbek, and A. Him, "Hepatoprotective effects of Pimpinella anisum seed extract in rats," Pharmacologyonline, vol. 3, pp. 870-874, 2008.

[233] K. M. Al-Ismail and T. Aburjai, "Antioxidant activity of water and alcohol extracts of chamomile flowers, anise seeds and dill seeds," Journal of the Science of Food and Agriculture, vol. 84, no. 2, pp. 173-178, 2004.

[234] I. Gülçin, M. Oktay, E. Kireçci, and Ö. I. Küfrevığlu, "Screening of antioxidant and antimicrobial activities of anise (Pimpinella anisum L.) seed extracts," Food Chemistry, vol. 83, no. 3, pp. 371382, 2003.

[235] A. Tas, H. Özbek, N. Atasoy, M. E. Altug, and E. Ceylan, "Evaluation of analgesic and antiinflammatory activity of Pimpinella anisum fixed oil extract," Indian Veterinary Journal, vol. 83, no. 8, pp. 840-843, 2006.

[236] R. E. Gosselin, R. P. Smith, and H. C. Hodge, Clinical Toxicology of Commercial Product, vol. 2, Williams \& Wilkins, Baltimore, Md, USA, 5th edition, 1984.

[237] O. Hanefi, O. Mustafa, O. Abdurrahman, C. Ebubekir, and Y. Zabit, "Determination of lethal doses of volatile and fixed oils 
of several plants," Eastern Journal of Medicine, vol. 9, no. 1, pp. 4-6, 2002.

[238] A. I. Mohamed and A. S. Hussein, "Chemical composition of purslane (Portulaca oleracea)," Plant Foods for Human Nutrition, vol. 45, no. 1, pp. 1-9, 1994.

[239] E. S. Elkhayat, S. R. M. Ibrahim, and M. A. Aziz, "Portulene, a new diterpene from Portulaca oleracea L.," Journal of Asian Natural Products Research, vol. 10, no. 11, pp. 1039-1043, 2008.

[240] Y. Y. Lim and E. P. L. Quah, "Antioxidant properties of different cultivars of Portulaca oleracea," Food Chemistry, vol. 103, no. 3, pp. 734-740, 2007.

[241] K. Chan, M. W. Islam, M. Kamil et al., "The analgesic and anti-inflammatory effects of Portulaca oleracea L. subsp. sativa (Haw.) Celak," Journal of Ethnopharmacology, vol. 73, no. 3, pp. 445-451, 2000.

[242] K. Y. Musa, A. Ahmed, G. Ibrahim et al., "Toxicity studies on the methanolic extract of Portulaca oleracea L. (Fam. Portulacaceae)," Journal of Biological Sciences, vol. 7, no. 7, pp. 1293-1295, 2007.

[243] I. A. Wasfi, A. K. Bashir, A. A. Abdalla, N. R. Banna, and M. O. M. Tanira, "Antiinflammatory activity of some medicinal plants of the United Arab Emirates," Pharmaceutical Biology, vol. 33, no. 2, pp. 124-128, 1995.

[244] S. E. I. Adam, "Experimental Rhazya stricta toxicosis in rats," Veterinary and Human Toxicology, vol. 41, no. 1, pp. 5-8, 1999.

[245] M. Stuart, The Encyclopedia of Herbs and Herbalism, Orbis Publishing, London, UK, 1979.

[246] E. P. Clause, E. T. Varo, and R. B. Lynn, Pharmacognosy, Henry Kimpton, London, UK, 1971.

[247] S. Rafatullah, J. S. Mossa, A. M. Ageel, M. A. Al-Yahya, and M. Tariq, "Hepatoprotective and safety evaluation studies on Sarsaparilla," International Journal of Pharmacognosy, vol. 29, no. 4, pp. 296-301, 1991.

[248] R. Bomford, "Immunomodulators from plants and fungi," Phytotherapy Research, vol. 2, no. 4, pp. 159-164, 1988.

[249] C. U. Nwaigwe, I. I. Madubunyi, S. C. Udem, and C. O. Nwaigwe, "Methanolic root extract of Olax viridis protects the liver against acetaminophen-induced liver damage," Research Journal of Medicinal Plant, vol. 6, no. 5, pp. 395-405, 2012.

[250] R. B. Drotman and G. T. Lawhorn, "Serum enzymes as indicators of chemically induced liver damage," Drug and Chemical Toxicology, vol. 1, no. 2, pp. 163-171, 1978.

[251] K. Raju, G. Anbuganapathi, V. Gokulakrishnan, B. Rajkapoor, B. Jayakar, and S. Manian, "Effect of dried fruits of Solanum nigrum Linn. against $\mathrm{CCl}_{4}$-induced hepatic damage in rats," Biological and Pharmaceutical Bulletin, vol. 26, no. 11, pp. 16181619, 2003.

[252] C.-C. Hsieh, H.-L. Fang, and W.-C. Lina, "Inhibitory effect of Solanum nigrum on thioacetamide-induced liver fibrosis in mice," Journal of Ethnopharmacology, vol. 119, no. 1, pp. 117-121, 2008.

[253] U. S. Akula and B. Odhav, "In vitro 5-lipoxygenase inhibition of polyphenolic antioxidants from undomesticated plants of South Africa," Journal of Medicinal Plants Research, vol. 2, no. 9, pp. 207-212, 2008.

[254] X.-F. Cai, Y.-W. Chin, S.-R. Oh, O.-K. Kwon, K.-S. Ahn, and H.K. Lee, "Anti-inflammatory constituents from Solanum nigrum," Bulletin of the Korean Chemical Society, vol. 31, no. 1, pp. 199-201, 2010.

[255] M. M. Abd Elkawy, G. Z. A. Soliman, E. Abd-El Mobd'ea, and Abd-El Rehim, "Effect of Solanum nigrum Linn. against lambda cyhalothrin-induced toxicity in rats," IOSR-Journal of Pharmacy and Biological Sciences, vol. 5, no. 5, pp. 55-62, 2013.

[256] A. M. Youssef, M. A. Al-Fredan, and A. A. Fathi, "Floristic composition of lake Al-Asfar, Alahsa, Saudi Arabia," International Journal of Botany, vol. 5, no. 2, pp. 116-125, 2009.

[257] J. K. Patra, N. K. Dhal, and H. N. Thatoi, "In vitro bioactivity and phytochemical screening of Suaeda maritima (Dumort): a mangrove associate from Bhitarkanika, India," Asian Pacific Journal of Tropical Medicine, vol. 4, no. 9, pp. 727-734, 2011.

[258] W. M. Bandaranayake, "Traditional and medicinal uses of mangroves," Mangroves and Salt Marshes, vol. 2, no. 3, pp. 133148, 1998.

[259] R. S. Orfali, Phytochemical and Biological Study of Tamarix nilotica Growing in Saudi Arabia, King Saud University, 2005.

[260] S. Shenoy, K. Shwetha, K. Prabhu, R. Maradi, K. L. Bairy, and T. Shanbhag, "Evaluation of antiinflammatory activity of Tephrosia purpurea in rats," Asian Pacific Journal of Tropical Medicine, vol. 3, no. 3, pp. 193-195, 2010.

[261] T. Hussain, S. Fareed, H. H. Siddiqui, M. Vijaykumar, and C. V. Rao, "Acute and subacute oral toxicity evaluation of Tephrosia purpurea extract in rodents," Asian Pacific Journal of Tropical Disease, vol. 2, no. 2, pp. 129-132, 2012.

[262] H. Kalantari, H. Forouzandeh, M. E. Azemi, I. Rashidi, and M. Goudarzi, "Study of the protective effect of Teucrium polium L. extract on acetaminophen-induced hepatotoxicity in mice," Iranian Journal of Pharmaceutical Research, vol. 12, no. 1, pp. 123-129, 2013.

[263] A. Bomzon, S. Shtukmaster, and P. Ljubuncic, "The effect of an aqueous extract of Teucrium polium on glutathione homeostasis in vitro: a possible mechanism of its hepatoprotectant action," Advances in Pharmacological Sciences, vol. 2010, Article ID 938324, 7 pages, 2010.

[264] J. Shakhanbeh and O. Atrouse, “Teucrium polium inhibits nerve conduction and carrageenan-induced inflammation in the rat skin," Turkish Journal of Medical Sciences, vol. 31, no. 1, pp. 1521, 2001.

[265] F. Capasso, R. Cerri, P. Morrica, and F. Senatore, "Chemical composition and anti-inflammatory activity of an alcoholic extract of Teucrium polium L.," Bollettino della Societa Italiana di Biologia Sperimentale, vol. 59, no. 11, pp. 1639-1643, 1983.

[266] K. H. Abu Sitta, M. S. Shomah, and A. S. Salhab, "Hepatotoxicity of 'Teucrium polium' L. tea: supporting evidence in mice models," Australian Journal of Medical Herbalism, vol. 21, no. 4, pp. 106-109, 2009.

[267] A. R. Soylu, B. Sivri, and Y. Bayraktar, "Hepatoxicity of Teucrium polium," Turkish Journal of Gastroenterology, vol. 9, no. 2, pp. 196-197, 1998.

[268] A. Mattei, P. Rucay, D. Samuel, C. Feray, M. Reynes, and H. Bismuth, "Liver transplantation for severe acute liver failure after herbal medicine (Teucrium polium) administration," Journal of Hepatology, vol. 22, no. 5, pp. 597-562, 1995.

[269] I. Baitar, Jameul Mufradat al Advia wal Aghzia (Urdu Translation by CCRUM), vol. 2, CCRUM, Ministry of Health and Family Welfare, New Delhi, India, 2nd edition, 2000.

[270] N. O. Aguilar, Trianthema portulacastrum L. Plant Resources of South East Asia 12(2): Medicinal and poisonous Plants 2, Backhuys, 2001.

[271] C. Muthu, M. Ayyanar, N. Raja, and S. Ignacimuthu, "Medicinal plants used by traditional healers in Kancheepuram District of Tamil Nadu, India," Journal of Ethnobiology and Ethnomedicine, vol. 2, article 43, 2006. 
[272] G. Kumar, G. S. Banu, P. V. Pappa, M. Sundararajan, and M. R. Pandian, "Hepatoprotective activity of Trianthema portulacastrum L. against paracetamol and thioacetamide intoxication in albino rats," Journal of Ethnopharmacology, vol. 92, no. 1, pp. 3740, 2004.

[273] A. Mandal, R. Karmakar, S. Bandyopadhyay, and M. Chatterjee, "Antihepatotoxic potential of Trianthema portulacastrum in carbon tetrachloride-induced chronic hepatocellular injury in mice: reflection in haematological, histological and biochemical characteristics," Archives of Pharmacal Research, vol. 21, no. 3, pp. 223-230, 1998.

[274] G. Kumar, G. S. Banu, and M. R. Pandian, "Evaluation of the anti-oxidant activity of Trianthema portulacastrum L.," Indian Journal of Pharmacology, vol. 37, no. 5, pp. 331-333, 2005.

[275] S. B. Vohora, S. A. Shah, S. A. H. Naqvi, S. Ahmad, and M. S. Khan, "Studies on Trianthema portulacastrum," Planta Medica, vol. 47, no. 2, pp. 106-108, 1983.

[276] M. Asif, M. Atif, A. S. A. Malik, Z. C. Dan, I. Ahmad, and A. Ahmad, "Diuretic activity of Trianthema portulacastrum crude extract in albino rats," Tropical Journal of Pharmaceutical Research, vol. 12, no. 6, pp. 967-972, 2013.

[277] P. Kavitha, R. Ramesh, G. Bupesh, A. Stalin, and P. Subramanian, "Hepatoprotective activity of Tribulus terrestris extract against acetaminophen-induced toxicity in a freshwater fish (Oreochromis mossambicus)," In Vitro Cellular and Developmental Biology-Animal, vol. 47, no. 10, pp. 698-706, 2011.

[278] M. Sambasivam, R. Ravikumar, R. Thinagarbabu, C. Davidraj, and S. Arvind, "Hepatoprotective potential of Azima tetracantha and Tribulus terrestris on ferrous sulfate-induced toxicity in rat," Bangladesh Journal of Pharmacology, vol. 8, no. 3, pp. 357360, 2013.

[279] J.-X. Li, Q. Shi, Q.-B. Xiong et al., "Tribulusamide A and B, new hepatoprotective lignanamides from the fruits of Tribulus terrestris: indications of cytoprotective activity in murine hepatocyte culture," Planta Medica, vol. 64, no. 7, pp. 628-631, 1998.

[280] D. Zheleva-Dimitrova, D. Obreshkova, and P. Nedialkov, "Antioxidant activity of Tribulus terrestris-a natural product in infertility therapy," International Journal of Pharmacy and Pharmaceutical Sciences, vol. 4, no. 4, pp. 508-511, 2012.

[281] B. Baburao, G. Rajyalakshmi, A. Venkatesham, G. Kiran, A. S. Sunder, and B. G. Rao, "Anti-inflammatory and antimicrobial activities of methanolic extract of Tribulus terrestris Linn. plant," International Journal of Chemical Sciences, vol. 7, no. 3, pp. 18671872, 2009.

[282] M. R. Aslani, A. R. Movassaghi, M. Mohri, M. Pedram, and A. Abavisani, "Experimental Tribulus terrestris poisoning in sheep: clinical, laboratory and pathological findings," Veterinary Research Communications, vol. 27, no. 1, pp. 53-62, 2003.

[283] M. R. Aslani, A. R. Movassaghi, M. Mohri, V. Ebrahim-pour, and A. N. Mohebi, "Experimental Tribulus terrestris poisoning in goats," Small Ruminant Research, vol. 51, no. 3, pp. 261-267, 2004.

[284] A. H. Talasaz, M.-R. Abbasi, S. Abkhiz, and S. DashtiKhavidaki, "Tribulus terrestris-induced severe nephrotoxicity in a young healthy male," Nephrology Dialysis Transplantation, vol. 25, no. 11, pp. 3792-3793, 2010.

[285] H. B. Arcasoy, A. Erenmemisoglu, Y. Tekol, S. Kurucu, and M. Kartal, "Effect of Tribulus terrestris L. saponin mixture on some smooth muscle preparations: a preliminary study," Bollettino Chimico Farmaceutico, vol. 137, no. 11, pp. 473-475, 1998. 


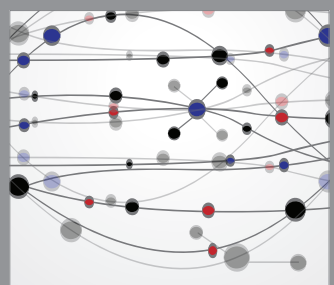

The Scientific World Journal
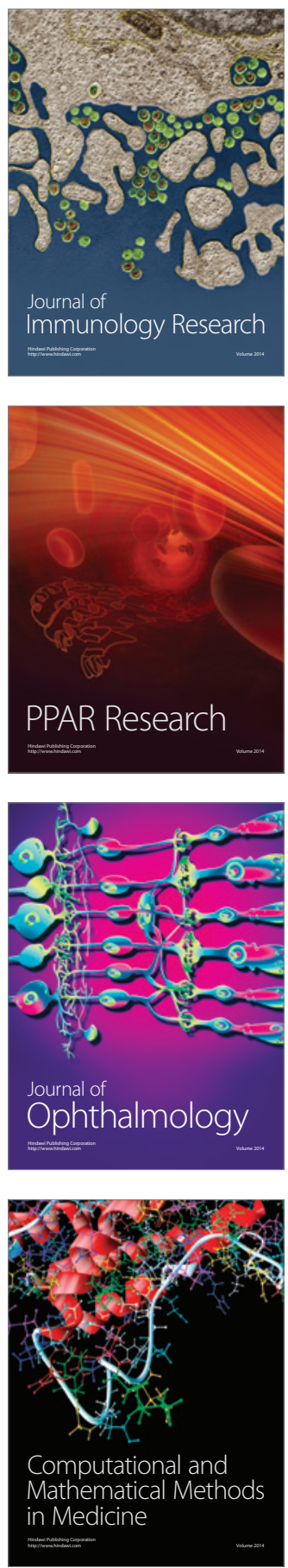

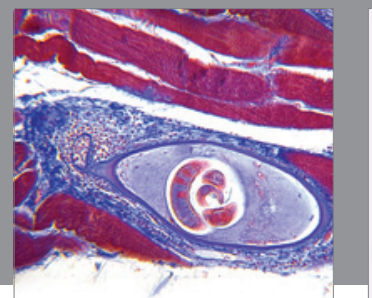

Gastroenterology

Research and Practice
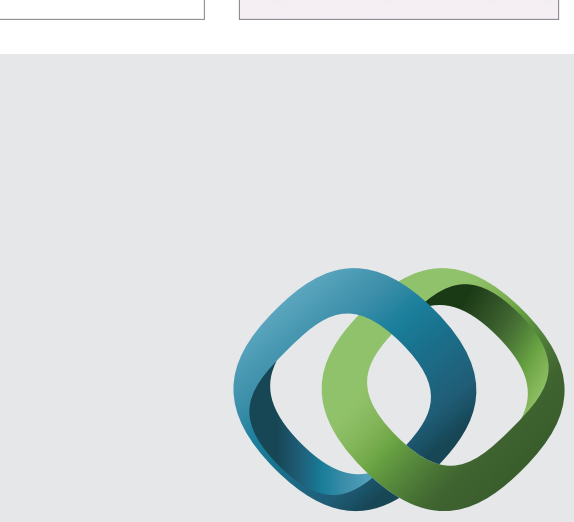

\section{Hindawi}

Submit your manuscripts at

http://www.hindawi.com
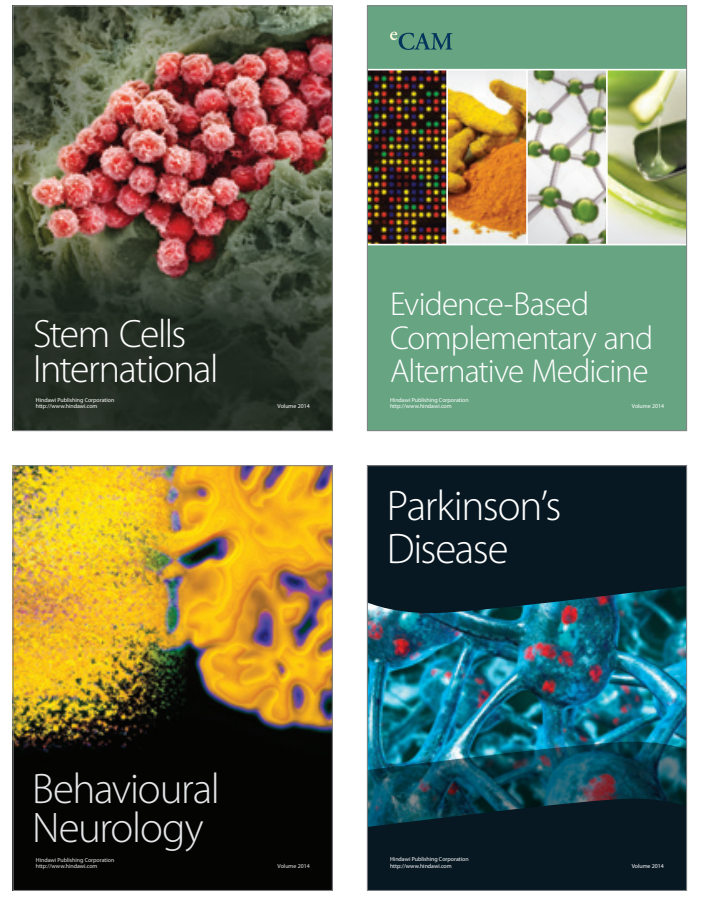
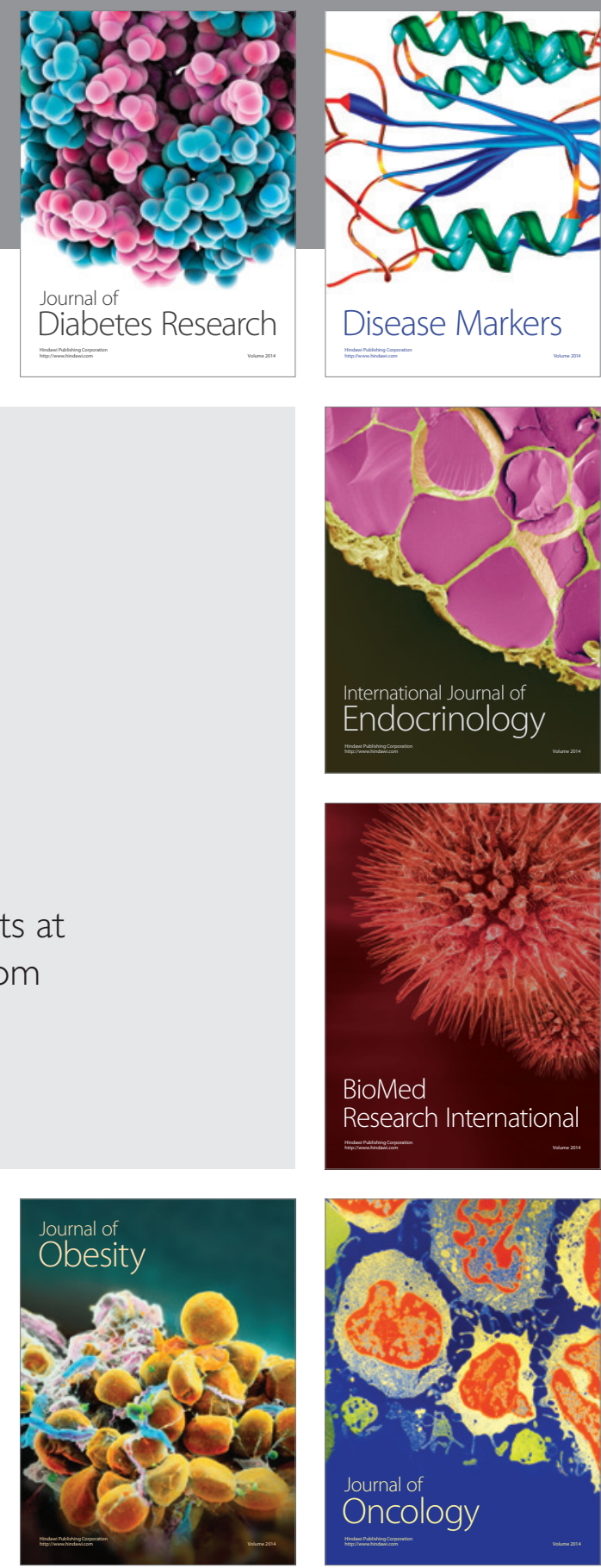

Disease Markers
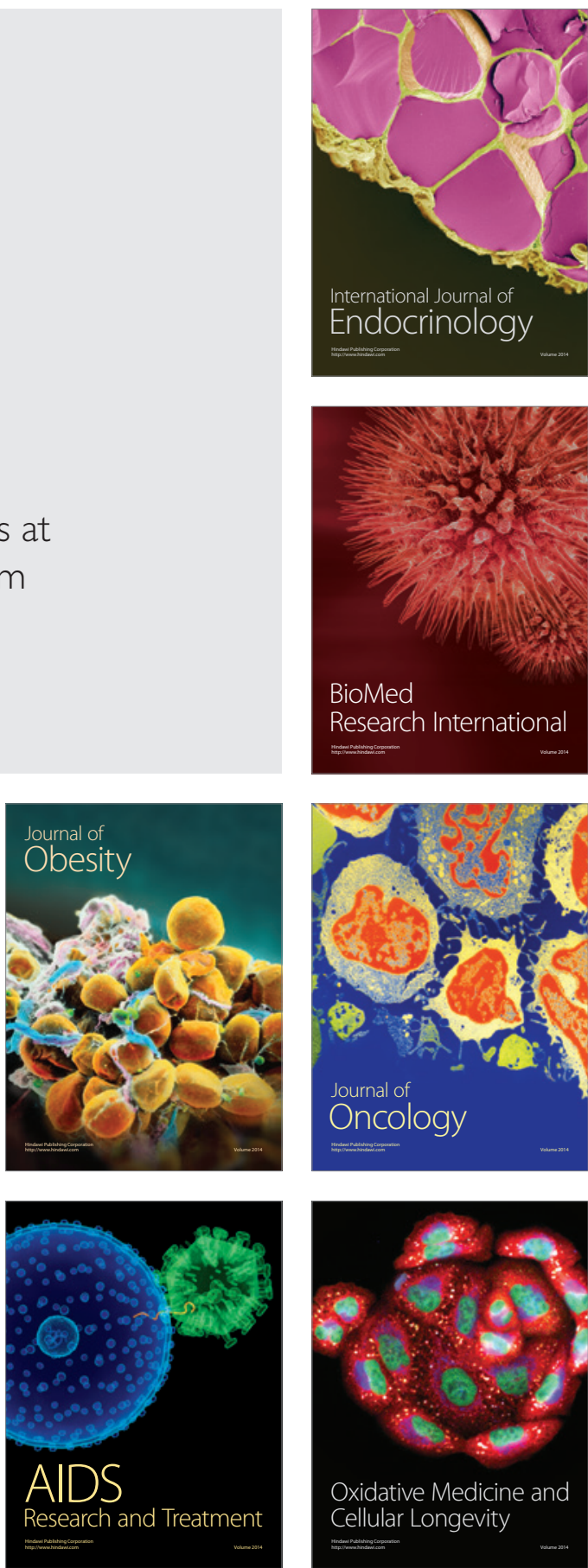